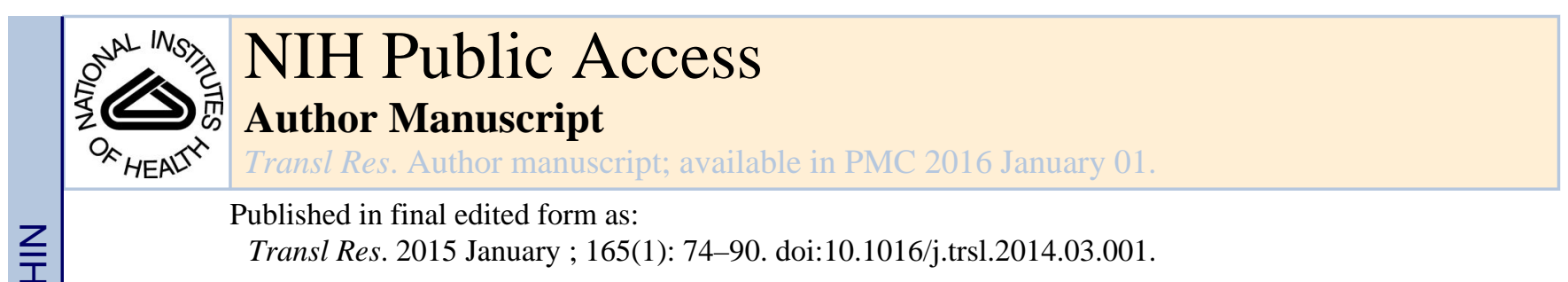

\title{
Epigenetics of Lung Cancer
}

Scott M. Langevin ${ }^{1}$, Robert A. Kratzke ${ }^{2}$, and Karl T. Kelsey ${ }^{3,4, \dagger}$

${ }^{1}$ Department of Environmental Health, University of Cincinnati College of Medicine, Cincinnati, $\mathrm{OH}$

${ }^{2}$ Department of Medicine, Division of Hematology, Oncology, and Transplantation, University of Minnesota Medical School, Minneapolis, MN

${ }^{3}$ Department of Epidemiology, Brown University, Providence, RI

${ }^{4}$ Department of Pathology and Laboratory Medicine, Brown University, Providence, RI

\section{Abstract}

Lung cancer is the leading cause of cancer-related mortality in the United States. Epigenetic alterations, including DNA methylation, histone modifications, and non-coding RNA expression, have widely been reported in the literature to play a major role in the genesis of lung cancer. The goal of this review is to summarize the common epigenetic changes associated with lung cancer to give some clarity to its etiology, and provide an overview of the potential translational applications of these changes, including applications for early detection, diagnosis, prognostication, and therapeutics.

\section{Keywords}

DNA methylation; histone modifications; microRNA; lnc-RNA; non-coding RNA; biomarkers; NSCLC; small cell carcinoma; pulmonary carcinoma

\section{INTRODUCTION}

Despite large-scale reductions in cigarette consumption over the past several decades, lung cancer remains the leading cause of cancer-related mortality in the United States and is the second leading cause of death overall, after heart disease [1]. While lung cancer rates have steadily declined among men since the 1980s and seem to have plateaued among women, there still remain an estimated 228,190 new cases and 159,480 deaths each year [1]. This high mortality rate is driven by the high incidence of this disease coupled with its dismal 5year survival rate of only $17 \%$ [1].

() 2014 Mosby, Inc. All rights reserved.

${ }^{\dagger}$ Corresponding author: 70 Ship Street, Box G-E5, Providence, RI 02912, Phone: 401-863-6420, Fax: 401-863-9008, karl_kelsey@brown.edu.

All authors have all read the journal's authorship agreement and policy on conflicts of interest and have no conflicts to declare.

Publisher's Disclaimer: This is a PDF file of an unedited manuscript that has been accepted for publication. As a service to our customers we are providing this early version of the manuscript. The manuscript will undergo copyediting, typesetting, and review of the resulting proof before it is published in its final citable form. Please note that during the production process errors may be discovered which could affect the content, and all legal disclaimers that apply to the journal pertain. 
The vast majority of lung cancer is can be characterized as small cell (neuroendocrine) carcinoma (SCLC) or non-small cell carcinoma (NSCLC), which broadly includes squamous cell carcinoma, adenocarcinoma, and large cell carcinoma subtypes [2]. NSCLC is by far the more common of the types, accounting for approximately $85 \%$ of all lung cancer cases [3]. While these histologies share a common organ of origin and some molecular attributes, they also exhibit unique molecular traits and represent distinct diseases, and it has become clear that it is important to make the distinction between the histologies for the purpose of treating the disease.

While smoking remains the major risk factor for all histologies (especially small cell and squamous cell carcinoma), it is important to note that only some $10 \%$ of smokers will ultimately develop lung cancer [4]. Moreover, not all lung cancer patients have a smoking history, as there are other risk factors for the disease. Adenocarcinoma, which accounts for approximately $37 \%$ of all lung cancers in the United States, is the most common form among non-smokers [5]. Globally, an estimated $15 \%$ of men and 53\% of women with lung cancer are never-smokers [6]. Other risk factors for the disease include radon, asbestos, and environmental/occupational exposure to polycyclic aromatic hydrocarbons and other pollutants [2]. However, as with smoking, not everyone who is exposed to these environmental factors will go on to develop lung cancer.

The carcinogenic process is driven by the accumulation of genetic and epigenetic alterations that result in dysregulation of key oncogenes, tumor suppressor genes, and DNA repair/ housekeeping genes. The probability of incurring these pathologically important events is largely dependent upon the individual exposome in conjunction with interpersonal phenotypic variability. While genetic heterogeneity accounts for some of the variable risk, it does not explain this phenomenon in toto [7]. Epigenetic variability, including DNA methylation, histone modifications, and non-coding RNA expression, also contribute the phenotypic makeup of an individual (e.g. xenobiotic metabolism, DNA repair capacity, immunity, etc.) and, accordingly, risk of malignancy.

This underscores the importance of enhancing our knowledge of lung cancer epigenetics (in addition to genetics) to fully comprehend the pathogenesis of this disease. Moreover, continued expansion our understanding of various epigenetic events involved with different types of lung cancer expands the potential battery of diagnostic and prognostic biomarkers available to clinicians, as well as introducing new avenues for the discovery of novel therapeutic targets. The primary objective of this review is to summarize the common epigenetic events in lung cancer and provide an overview of the potential translational applications of these events for the management of this disease.

\section{EPIGENETICS \& ETIOLOGY}

\section{Tumorigenesis}

Lung cancer involves an accumulation of genetic and epigenetic events in the respiratory epithelium [8]. While somatic genetic aberrations, such as mutations and copy number alterations, play a well-known role in oncogenesis, epigenetic alterations are in fact more frequent than somatic mutations in lung cancer [9]. 
Tumor suppressor gene inactivation through promoter methylation, often referred to as hypermethylation, is a hallmark of lung cancer and is an early event in the carcinogenic process $[10,11]$. Promoter methylation of specific tumor suppressor genes, along with the overall number of hypermethylated genes, increases with neoplastic progression from hyperplasia to adenocarcinoma $[12,13]$. Promoter methylation can couple with mutation or deletion events to inactivate a tumor suppressor gene (i.e. a different inactivation event for each allele). This is because inactivation of one allele for dominantly acting suppressor gene loci is generally insufficient to lead to clonal selection, since the protein can still be produced from one normal allele. However, there is also evidence that, at some gene loci, both copies do not necessarily need to be inactivated to adversely impact the cell, but rather that partial inactivation of one allele, giving rise to haploinsufficiency, (i.e. one wild-type allele is insufficient to provide full functionality) can contribute to carcinogenesis [14]. In these cases, inactivation of one allele by promoter methylation would be sufficient for clonal selection.

Many of the tumor suppressor genes that are hypermethylated in lung cancer are also frequently hypermethylated in other types of solid tumors [6]. Some are specific, although many are not, similar to what is observed for somatic mutations. In premalignant and malignant states, promoter methylation is frequently observed in genes involved with crucial functions, including cell cycle control, proliferation, apoptosis, cellular adhesion, motility, and DNA repair.

Some of the most oft-studied genes in the context of promoter methylation in lung cancer include p16INK4a, RASSF1A, APC, RAR $, C D H 1, C D H 13, D A P K, F H I T$, and MGMT. While p16INK4a is frequently methylated, mutated, or deleted in NSCLC, with estimates for the prevalence of alteration of this gene are around $60 \%$, p14arf, which is also encoded on the $C D K N 2 A$ gene, is much less commonly inactivated ( 8-30\% of NSCLC) $[15,16]$. Moreover, although a common event in NSCLC, p16INK4a is disrupted in less than $10 \%$ of SCLC [15]. Additionally, RASSF 1A is deleted or methylated in 30-40\% of NSCLC and 70$100 \%$ of SCLC [15], FHIT is deleted or methylated in 40-70\% of NSCLC and 50-80\% of SCLC [15], and TSLCl is methylated in an estimated 85\% of NSCLC [15]. A more extensive list of known, commonly hypermethylated genes in lung cancer is provided in Table 1.

Hypermethylation of $C D K N 2 A$ may occur early in the genesis of some lung cancers, having been identified in premalignant lesions [69]. Promoter methylation of RASSF1A, APC, ESR 1, ABCB1, MTIG, and HOXC9 have been associated with Stage I NSCLC [70], suggesting that they too may occur relatively early on in the development of the cancer. $\mathrm{CpG}$ island methylation of homeobox-associated genes is also common Stage I lung cancer, appearing in nearly all early-stage tumors [71]. Conversely, other commonly hypermethylated genes, such as $h D A B 2 I P, H$-Cadherin, DAL-1, and $F B N 2$, have been associated with advanced stage NSCLC $[64,72,73]$, suggesting that these changes may occur at a later point in the carcinogenic process. It is important to note, however, that later involvement does not preclude the importance of the modification in the development of the disease, as they may play key roles in the ability of the cancer to continue to flourish in its advanced state, evade host immunity or exogenous cancer treatments, or to metastasize 
locally and/or systemically. Further, it is critical that these generalized "temporal" observations are kept in perspective, as lung cancer is a very heterogeneous disease and each tumor is unique; an early event in one tumor may not occur until later on in another. Moreover, it must be considered that most of these observations are based on cross-sectional measurement of malignant or premalignant tissue, and that linear consideration of the sequential timing of molecular aberrations likely represents a gross oversimplification of cancer development and progression.

There is some evidence for $\mathrm{CpG}$ island methylator phenotype (CIMP), a tumor phenotype characterized by widespread hypermethylation, in lung cancer [74-77]. This is not wholly surprising, given that DNA methyltransferases (DNMT), the group of enzymes that catalyze the covalent attachment of the methyl group to the cytosine base, are upregulated in NSCLC $[68,78,79]$.

In contrast to gene-specific hypermethylation, which can occur early on in cancer development, genomic hypomethylation, a genome-wide loss of methylation, may be a late event in the genesis of lung cancer, at least for adenocarcinoma [5]. However, there is not presently a clear consensus on the timing, as Anisowicz found that hypomethylation was associated with NSCLC progression from normal to lung cancer [80]. Regardless, widespread hypomethylation has been associated with genomic instability in NSCLC [81] and can result in oncogene activation [82, 83] and loss of imprinting [84]. In lung cancer, hypomethylation tends to occur at nuclear elements, LTR elements, segmental duplicates, and subtelomeric regions (loss of methylation is much less common at non-repetitive sequences) [85]. In addition to the genomic loss of methyl content, gene-specific hypomethylation has been reported for several loci, including MAGEA [86, 87], TKTL1 [86, 88], BORIS [89, 90], DDR1 [31] 14-3-3 [ [91, 92], and TMSB10 [83, 93]. MAGE overexpression with an associated loss of methylation has been observed in $75-80 \%$ of NSCLC [94].

$\mathrm{CpG}$ methylation can also induce point mutations through deamination of 5-methylcytosine (5-meC) or enhancement of exongenous carcinogens. Methylated cytosine can undergo hydrolytic deamination causing a $\mathrm{C}$ to $\mathrm{T}$ transition [95]. More than $30 \%$ of disease-related germline point mutations occur at $\mathrm{CpG}$ dinucleotides [95]. Furthermore, nearly half of all somatic and one-third of all germline p53 mutations take place at methylated $\mathrm{CpGs}$, and many common p53 mutations that manifest in somatic cells are caused by $\mathrm{C}$ to $\mathrm{T}$ transitions, including "hot spot" mutations at codons 248, 273, and 282 [96]. The risk of p53 mutation at 5 -meC is 10-fold that of unmethylated cytosine, and $\mathrm{CpG}$ dinucleotides in these regions have been observed to be methylated in normal tissue [96]. Secondly, DNA methylation can enhance the mutagenic effect of exogenous carcinogens [95]. An example of this is the affinity of benzo(a)pyrene diol epoxide (BPDE) for adduct formation on guanine bases adjacent to 5-meC, resulting in $\mathrm{G}$ to $\mathrm{T}$ transversions in aerodigestive tract cancers in smokers [97-99]. Similarly, acrolein has an affinity for binding 5-meC, which can induce C to T transitions [100].

Histone deacetylases (HDAC) are overexpressed in lung cancer [101-103]. HDACs catalyze the removal of acetyl groups on the histone tail resulting in a transcriptionally inactive 
heterochromatic state [104]. Likewise, SIN3A (part of an HDAC repressor complex) is downregulated in NSCLC [105]. Cross talk occurs, mediated by proteins with methylbinding domains that can recruit histone modifying enzymes (MBDs, KAISO, MeCP2), such as HDAC, that closely couples DNA methylation and histone modifications [9]. Relative to normal lung, lung cancer undergoes H4K5/H4K8 hyperacetylation, H4K12/ H4K16 hypoacetylation, and H4K20me3 [106]. Lower global levels of H4K20me3 can be detected in precursor lesions and is particularly common in squamous cancers [106].

Other post-translational modifiers that have been reported as overexpressed in lung cancer relative to normal lung tissue include polycomb group genes $(\mathrm{PcG})$, which are crucial epigenetic regulators of stem cell (and cancer stem cell) survival and pluripotency. Specifically, upregulation has been observed for PcGs that form the Polycomb repressive complexes (PRC1 and PRC2) [107-118], particularly for the respective catalytic subunits, B-cell-specific Moloney Murine Leukemia Virus Integration Site 1 (BMI-1), which is involved in gene silencing through ubiquitylation of histone 2A (H2A) [119], and Enhancer of Zeste Homologue 2 (EZH2) [111-114, 116-118], which controls gene expression through histone H3 Lysine 27 trimethylation or by interacting with DNMTs to signal transcriptional repression [119].[109] BMI-1 is overexpressed at higher levels in SCLC relative to NSCLC [109], although, unlike EZH2, it is constitutively expressed in normal lung tissue [120, 121]. Upregulation of Polycomb repressive complex genes have been associated with lung cancer proliferation, survival, and epithelial-mesenchymal transition (EMT) [108, 109, 112, 122, 123].

Non-coding RNA are a class of RNA sequences that are transcribed but do not encode proteins. MicroRNA are small non-coding RNA molecules ( 18-22 nt) that can negatively regulate the expression of hundreds of mRNA targets and are frequently dysregulated in lung cancer. Two recent meta-analyses have reported on microRNAs for which expression is commonly reported to be dysregulated in lung cancer [124, 125], which are in summarized in Table 2. In particular, miR-196a and miR-200b are highly overexpressed in lung cancer, with estimated fold-changes exceeding 23- and 37-times, respectively [124]. Much less is presently known about the precise functions of long non-coding RNA (lncRNA), although there is evidence that they function as protein regulators and structural organizers, in addition to regulation of gene expression [126]. Two lncRNA in particular that have been implicated in lung cancer are metastasis-associated lung adenocarcinoma transcript 1 (MALAT1) and Hox transcript antisense intergenic RNA (HOTAIR). MALAT1 is a highly conserved lncRNA sequence of $\sim 8000 \mathrm{nt}$ in length [127] that is overexpressed in NSCLC (including adenocarcinoma, squamous cell carcinoma, and large cell carcinoma) [128, 129] and is thought to play a role in cell motility, invasion, and metastasis, at least in part through posttranslational inhibition of expression of genes regulating these functions [130-132].

HOTAIR is also a highly conserved lncRNA (at least in mammals) that is also reported to be overexpressed in lung cancer [133-135] and interacts with PRC2 and histone regulatory complexes, and regulates HOXD expression [126].

There have also been several well-documented examples of interaction between DNA methylation and microRNAs in lung cancer. For example, miR-124a [136], miR-34b/c [137, 138], miR-886-3p (in SCLC) [139], miR-9-3 [140] and miR-193a [140] have all been 
reported as frequently hypermethylated in lung tumors, while let-7a-3 [141] is often hypomethylated. Moreover, miR-29 targets the transcripts of de novo DNMT (DNMT3a/b). Additionally, expression of miR-29 is inversely associated with DNMT3a/b expression in lung tumors, and has been shown to restore normal DNA methylation patterns in experimental models (in vitro and in vivo) [142].

Some epigenetic alterations reported for lung cancer may be smoking-specific (i.e. only found in lung tumors of smokers). Genes reported to undergo smoking-specific promoter methylation include $A P C, F H I T, R A S S F 1 A$, and CCND2 [21, 35, 40, 143, 144]. Also, the frequency of promoter methylation of p16INK4a, MGMT, RASSF1A, MTHFR, and FHIT is higher in the NSCLC tumors of smokers relative to non-smokers [21, 22, 145-147]. Moreover, RAR $\beta$, pI6INK4a, FHIT, and RASSF1A promoter methylation increases with increasing smoking intensity [21,148-150]. Interestingly, genes whose silencing is associated with duration or amount of tobacco smoking are likely later stage contributors to this disease, as long-term exposure to carcinogenic stimuli would imply a later selection of existing clones. Experimentally, genomic hypomethylation and promoter methylation of RASSF1A and RAR $\beta$ were observed when normal small airway epithelial cells and immortalized bronchial epithelial were exposed to cigarette smoke condensate [151]. There is also experimental evidence indicating that cigarette condensate decreases nuclear levels of $\mathrm{H} 4 \mathrm{~K} 16 \mathrm{ac}$ and H4K2me3 in respiratory epithelial cells [152]. Conversely, RASSF2, TNFRSF10, BHLHB5 and BOLL have been reported to be more frequently hypermethylated in NSCLC from never-smokers [153, 154].

DNMT1 expression is particularly high in lung cancer tumors of smokers [155]. The tobacco-specific nitrosamine, 4-(methylnitrosamino)-1-(3-pyridyl)-1-butanone (NNK), has been associated with increased levels of DNMT1. Experimental evidence indicates that NNK does not affect the actual DNMT1 mRNA level but rather inhibits DNMT1 degradation via Akt signaling, which stabilizes the DNMT1 protein by decreasing ubiquitylation, resulting in elevated accumulation and, accordingly, aberrant tumor suppressor gene methylation $[151,155,156]$. More specifically, NNK stimulates Akt, which inactivates GSK3 $\beta$ ser/thr kinase, which would otherwise phosphorylate DNMT1 and recruit ubiquitylases. This is similarly observed for laryngeal [157] and esophageal squamous cancers [158]. Corroborating this point, NNK has been shown to induce promoter hypermethylation of tumor suppressor genes in lung tumors in mice and rats [159-161].

Moreover, chronic inflammation, which occurs in response to cigarette smoking, also plays an important role in lung cancer development, stimulating cellular turnover and proliferation. Inflammation has long been associated with DNA methylation in lung cancer [162-164]. There is evidence that reactive oxygen species (ROS), such as are generated during chronic inflammation, target transcriptional repressors, giving rise to increased levels of DNA methylation [165]. Cigarette smoke also inhibits the metabolism and storage of folate [166]. Nitrates, nitrous oxide, cyanates and isocyanates found in tobacco smoke have been shown to transform folate, a major source of methyl groups for one-carbon metabolism, into a biologically inactive compound in experimental models [167, 168]. In further support of this, reduced serum folate levels have been observed in smokers relative to non-smokers $[169,170]$. One-carbon metabolism is a critical pathway in the DNA 
methylation process, and depletion of folate can negatively impact the availability of sadenosylmethionine (SAM), the primary methyl donor in the cytosine methylation reaction. Consequently, folate deficiency can result in chromosomal damage through impaired nucleotide synthesis and aberrant DNA methylation [171, 172].

To this point, any discussion in this review relating epigenetics to cancer risk factors has primarily focused on tobacco-smoke associated events. However, as discussed earlier, not all lung cancer patients, particularly adenocarcinoma patients, have a history of smoking. Exposure to radon gas is another major risk factor for lung cancer. Experimentally, radonexposed transformed bronchial epithelial cells exhibit altered microRNA expression profiles [173]. Further, a study of Chinese uranium miners found a dose-response between radon exposure and promoter methylation of p16INK4a and MGMT in sputum samples [174], although this was not observed in a similar study of uranium miners by Pulling et al [175].

\section{Tissue specificity}

Historically, adenocarcinoma and squamous cell carcinoma have been considered together, along with large cell carcinoma, in a heterogeneous class of lung cancers referred to as "non-small cell carcinoma'. However, this broad categorization may no longer be appropriate given our understanding of the biological and clinical differences between the histologic subtypes. Making the distinction between squamous cell carcinoma and adenocarcinoma based on morphology alone can be a challenge, necessitating additional markers for accurate discrimination.

The importance of discriminating NSCLC by histology was highlighted by data from a clinical trial of the VEGF antibody bevacizumab, in which elevated toxicity (severe pulmonary hemorrhage) was observed among patients with pulmonary squamous cell carcinoma but not adenocarcinoma [176]. Bevacizumab, in combination with platinumbased chemotherapy, has shown to be efficacious in non-squamous NSCLC in two Phase III trials (E4599 and AVAiL) [177, 178]. Further, Pemetrexed, an antimetabolite, is more efficacious in terms of overall and progression-free survival among patients with nonsquamous NSCLC relative to other histologies [179].

Distinct DNA methylation patterns have been identified for adenocarcinoma and squamous cell carcinoma, respectively [180-183]. Kwon and colleagues identified a methylation panel that could distinguish histologic class of NSCLC [180]. In another regard, Christensen and colleagues were able to accurately discriminate lung adenocarcinoma from mesothelioma, which can also be challenging but is very important to differentiate diagnostically, based on the DNA methylation profile [184]. There are no significant large-scale differences in overall DNA methylation levels by lung cancer histology [32], although there are locusspecific differences. Additionally, there are also reports of histology-specific microRNA expression patterns. For example, miR-205 is reported to be SCC-specific [185, 186], while miR-124a has been reported as specific for adenocarcinoma [136]. 


\section{Early detection and diagnosis}

Lung cancer mortality could be significantly reduced with earlier detection of the disease. However, only about $15 \%$ of lung tumors are localized at diagnosis, with the majority presenting at an advanced stage [2]. Five-year survival for lung cancer is markedly better for early-stage patients, with a less than $10 \%$ 5-year survival for advanced stage patients versus better than $70 \%$ for early-patients [187]. Spiral computed tomography (CT) has shown promise for the early detection of lung cancer but has a high false-positive rate [188], with up to up to $30 \%$ of indeterminate nodules identified by CT ultimately found to be benign [189], indicating a need for development of additional markers to enhance the specificity.

As previously discussed, promoter hypermethylation can be an early event in lung carcinogenesis, and as such, may have utility in early detection of the disease. For instance, promoter hypermethylation of $p 16 I N K 4 a$ has been observed in NSCLC precursor lesions $[13,18]$, and PTPRN2 promoter methylation is reported to be an early event in pulmonary adenocarcinoma, with detectable changes in the premalignant atypical adenomatous hyperplasia [5].

Importantly, some of these early epigenetic events can be detected by non- or minimallyinvasive sample collection techniques, an important characteristic for cancer screening applications. For example, aberrant DNA methylation can be detected in sputum [190, 191], bronchoalveolar aspirate/lavage [39, 145, 192-194], and saliva [195, 196] in lung cancer patients. Furthermore, $C D K N 2 A$ and $M G M T$ promoter methylation was detected in sputum up to 3-years prior to lung cancer diagnosis [20], and promoter methylation of p16INK4a, $M G M T, P A X 5 b, D A P K, G A T A 5$, and RASSF1A was detected in sputum 18 months prior to lung cancer diagnosis in another study [197]. However, specificity can be an issue for some of these early markers, as they can also be detected in individuals who will not ever go on to develop disease. To this point, promoter methylation of p16INK4a has been detected in sputum from former and current smokers [10], which underscores the importance of multimarker panels. However, not all single markers are non-specific, as exemplified by SHOX2 promoter methylation, which has demonstrated good sensitivity (68-78\%) and specificity $(95-96 \%)$ for NSCLC in bronchial aspirates $($ AUC $=86-94 \%)[51,193]$.

Additionally, cancer-specific DNA methylation [38, 198], microRNA [199, 200], and IncRNA [201] profiles have been identified in the blood of lung cancer patients. Metaanalysis on the diagnostic value of circulating microRNAs for lung cancer reports a metaROC of 0.92 [202], highlighting the potential diagnostic capacity.

\section{PROGNOSTIC BIOMARKERS}

Identification of novel biomarkers to aid in prediction of outcome and tumor response is of paramount importance to optimize therapeutic efficacy and prevent over- or under-treatment of lung cancer patients. Epigenetic biomarkers, in particular DNA methylation and microRNA expression, have unique properties that make them well-suited as potential prognostic markers, and accordingly have been widely studied and reported in the literature. 
Not surprisingly, many of the hypermethylated tumor suppressor genes that are implicated in lung cancer oncogenesis have also been reported to be associated with prognosis. Promoter methylation of RASSF1A [16, 36, 203], PTEN, DAPK [29], p16INK4a [21, 24, 203-206], Wif-1, CXCL12 [207], DLEC1 [208], MLH1 [208], CDH1 [58, 204], CDH13 [58], APC [41, 209], RUNX3 [36], SPARC, and DAL1 have all been associated with NSCLC outcome [22, $36,64,207,208,210-212]$. Additionally, DNMT1 overexpression in NSCLC is associated with decreased survival [78, 79, 213]; and DNMT3b only in patients <65 years old [213]. Along similar lines, CIMP has also been correlated with prognosis in NSCLC [74].

Relative to advanced stage lung cancers, chemotherapeutic recommendations are not as clear for early stage disease, with no true consensus as to the optimal approach [214]. Early stage lung cancer can be locally controlled but exhibits a high recurrence rate. Completely resected Stage IB and II tumors have a nearly $50 \%$ recurrence rate with a median time to recurrence of 1-year [215]. Fewer recur in Stage IA tumors, although certain IA subsets have high recurrence rates [216]. Methylation of p16INK4a, RASSF1A, CDH13, and APC has associated with early recurrence in surgically treated Stage I NSCLCs [210]. The combination of FHIT and p16INK4a promoter methylation has also been associated with recurrence in Stage I NSCLC [205].

Several global histone modifications have been associated with lung cancer survival; in particular decreased levels of H3K4diMe have been associated with poorer outcome [217, 218]. Additionally, the combination of several histone modifications have been reported to predict survival (H3K4me2, H3K9ac, H2AK5ac) [217], and H4K20me3 down-regulation has been associated with poorer survival in Stage I lung adenocarcinoma patients [106].

Higher expression of the PRC2 protein, EZH2, in NSCLC tumor tissue has been associated with worse overall [112, 118, 219] and disease-free survival [112] in several studies[117]. Likewise, BMI-1 expression has also been correlated with poorer patient outcomes [107, $121,220]$, and amplification and concordant overexpression of the PcG, $P H C 3$, has recently been associated with poorer outcomes in NSCLC [221].

Noncoding RNA have also been associated with lung cancer outcomes. A number of miRNA profiles of varying size and combination have been reported in tumor tissue [222]. In particular, mir-21and mir-155 have been the most oft studied as prognostic markers. In a recent meta-analysis, high miR-21 expression was associated with poorer overall survival in NSCLC (metaHR $=2.32,95 \%$ CI: $1.17-4.62 ; 6$ studies) and recurrence-free survival in adenocarcinoma (metaHR $=2.43,95 \%$ CI: $1.67-3.54 ; 3$ studies) [222]. Likewise, in the same meta-analysis, miR-155 was reported to be associated with poorer recurrence-free survival in NSCLC (metaHR $=1.42,95 \%$ CI: 1.10-1.83; 5 studies). Additionally, expression of the lncRNA MALATl has been associated with metastasis and poorer survival in NSCLC patients [128, 129], and HOTAIR expression has been associated with aggressive behavior, poorer outcomes in NSCLC [133-135, 223].

MicroRNA are often released from tissue during apoptosis or in exosomes or microvesicles and can be detected in the blood stream [224]. Circulating microRNA have been associated with prognosis. Several studies have reported an association between microRNA expression 
in blood or plasma and lung cancer outcome [225-232]. In particular, high-levels of circulating miR-21 have been consistently reported to be associated with outcome [225, 229, $231,232]$.

Methylation of circulating DNA may also be of use in outcome prediction, although it is important to distinguish free-circulating DNA from leukocytic DNA, since DNA methylation marks are tightly coupled to cellular differentiation and vary by cell type [233]. Thus, without careful study design, blood-based methylation profiles can be confounded by variation in relative circulating proportions of leukocyte types associated with outcome, such as immune response [7]. Ramirez and colleagues found that 14-3-3 sigma methylation in pretreatment serum may be an important predictor of NSCLC outcome in patients treated with platinum-based chemotherapy [234]. Similarly, Ponomaryova and colleagues found that increased methylation of $R A R \beta 2$ in circulating DNA was associated with lung cancer progression [235].

Recent evidence suggests that epigenetic mechanisms may be, at least in some instances, major players in treatment resistance. A number of studies have reported an association between altered expression of a variety of miRNA and sensitivity to gefitinib [236-241], erlotinib [242, 243], cisplatin [244-259], and radiotherapy [253, 260-265]. Elevated expression of HOTAIR [223] and EZH2 [117] have also each been associated with cisplatinresistance.

In a very elegant study, Sharma et al. demonstrated the capacity of a small subset of stemlike cells in two NSCLC cell-lines to undergo chromatin remodeling after treatment with erlotinib and cisplatin treatment to acquire treatment-resistance [266]. The authors found that the treatment-resistant tumor cells overexpressed the histone demethylase, KDM5A, and exhibited reduced $\mathrm{H} 3 \mathrm{~K} 4$ di- and trimethylation, and that these resistant cells were sensitive to HDAC inhibitors. These findings are extremely important, as they (1) demonstrate a major role for epigenetic plasticity in acquired drug-resistance, and (2) suggest the potential for histone post-translational modifications as therapeutic targets in drug-resistant NSCLC cells.

Intratumoral heterogeneity and clonal selection of treatment-resistant subpopulations of tumor cells has long been considered as another possible mechanism that can drive acquired treatment resistance in tumors. This notion of intratumoral genetic heterogeneity has recently been confirmed in renal cell carcinoma [267], and very likely is the case in other solid tumor types as well. Moreover, although not assessed in the study, cancer cells are presumably also epigenetically heterogenous within the tumor, as epigenetic alterations are common activating/inactivating events in carcinogenesis, and thus would be susceptible to stochastic selection as well. However, at this point, more research on this topic is needed to determine the extent and generalizability of these findings.

\section{PHARMACOLOGIC TARGETS}

Since DNA methylation and transcriptionally inactive heterochromatin conformation are frequent causes of tumor suppressor gene inactivation, therapeutic strategies that globally target epigenetic inactivation of genes have been pioneered for cancer treatment. 
Experimentally, HDAC [268-273] and DNMT [273, 274] inhibitors can restore tumor suppressor gene expression and, consequently, critical pathway function for small-cell and NSCLC patients. Other inhibitors of post-translational modifying proteins have also demonstrated promising antitumor properties in studies of lung cancer in vitro, including the Bromodomain and extra terminal domain (BET) protein inhibitor, JQ1 [275], and EZH2 inhibitors, 3-Deazaneplanocin A (DZNeP) [116, 276] and GSK126 [116].

Clinically, two classes of epigenetic regimens have been clinically tested for NSCLC [277]: (1) DNMT inhibitors and (2) HDAC inhibitors. The HDAC inhibitors vorinostat and romidepsin are each currently approved by the FDA for treatment of cutaneous T-cell lymphoma [278]. However, none are currently approved for treatment of lung cancer, although a recently completed clinical trial demonstrated promising results from combining 5-azacytidine, a DNA demethylating agent, with entinostat, an HDAC inhibitor, for the treatment of advanced chemorefractory NSCLC [279]. Additionally, other epigenetic treatment strategies are currently in clinical trials. The majority of these strategies combine HDAC inhibitors, with or without the DNMT inhibitor 5-azacytidine, with cytotoxic drugs, although one phase II trial is presently underway to test the efficacy of fluoro-2deoxycytidine (FdCyd), a DNMT inhibitor, in conjunction with tetrahydrouridine, a cytidine deaminase inhibitor that prevents FdCyd from being metabolized, in the treatment of NSCLC. A complete list of ongoing trials (as of December 31, 2013) is presented in Table 3 [140].

\section{CONCLUSIONS}

Epigenetics play a powerful role in the etiology of lung cancer and have potential utility as diagnostic and prognostic biomarkers. This may be particularly true for DNA methylation marks, due to their relative stability and amenability to PCR-based measurement, and microRNAs, which tend to be much more stable than mRNA and can each regulate up to hundreds of different gene transcripts. Expanding our understanding of how epigenetic events contribute to the genesis of lung cancer, and how these can be translated into clinically-relevant biomarkers and therapeutic targets, will enhance our ability to properly manage lung cancer and ultimately reduce the heavy global burden of this devastating disease.

\section{Acknowledgments}

This work was supported by the National Institutes of Health (R01CA100679 and R01CA126939 to KTK; and K22CA172358 to SML).

\section{References}

1. Siegel R, Naishadham D, Jemal A. Cancer statistics, 2013. CA: a cancer journal for clinicians. 2013; 63:11-30. [PubMed: 23335087]

2. Dela Cruz CS, Tanoue LT, Matthay RA. Lung cancer: epidemiology, etiology, and prevention. Clinics in chest medicine. 2011; 32:605-44. [PubMed: 22054876]

3. Lu F, Zhang HT. DNA methylation and nonsmall cell lung cancer. Anatomical record. 2011; 294:1787-95. 
4. Massion PP, Carbone DP. The molecular basis of lung cancer: molecular abnormalities and therapeutic implications. Respiratory research. 2003; 4:12. [PubMed: 14641911]

5. Selamat SA, Galler JS, Joshi AD, Fyfe MN, Campan M, Siegmund KD, et al. DNA methylation changes in atypical adenomatous hyperplasia, adenocarcinoma in situ, and lung adenocarcinoma. PloS one. 2011; 6:e21443. [PubMed: 21731750]

6. Herceg Z, Vaissiere T. Epigenetic mechanisms and cancer: an interface between the environment and the genome. Epigenetics : official journal of the DNA Methylation Society. 2011; 6:804-19. [PubMed: 21758002]

7. Langevin SM, Kelsey KT. The fate is not always written in the genes: epigenomics in epidemiologic studies. Environmental and molecular mutagenesis. 2013; 54:533-41. [PubMed: 23444110]

8. Dumitrescu RG. Epigenetic markers of early tumor development. Methods in molecular biology. 2012; 863:3-14. [PubMed: 22359284]

9. Brzezianska E, Dutkowska A, Antczak A. The significance of epigenetic alterations in lung carcinogenesis. Molecular biology reports. 2013; 40:309-25. [PubMed: 23086271]

10. Belinsky SA, Klinge DM, Dekker JD, Smith MW, Bocklage TJ, Gilliland FD, et al. Gene promoter methylation in plasma and sputum increases with lung cancer risk. Clinical cancer research : an official journal of the American Association for Cancer Research. 2005; 11:6505-11. [PubMed: 16166426]

11. Zochbauer-Muller S, Minna JD, Gazdar AF. Aberrant DNA methylation in lung cancer: biological and clinical implications. The oncologist. 2002; 7:451-7. [PubMed: 12401908]

12. Chung JH, Lee HJ, Kim BH, Cho NY, Kang GH. DNA methylation profile during multistage progression of pulmonary adenocarcinomas. Virchows Archiv : an international journal of pathology. 2011; 459:201-11. [PubMed: 21494759]

13. Licchesi JD, Westra WH, Hooker CM, Herman JG. Promoter hypermethylation of hallmark cancer genes in atypical adenomatous hyperplasia of the lung. Clinical cancer research : an official journal of the American Association for Cancer Research. 2008; 14:2570-8. [PubMed: 18451218]

14. Berger AH, Knudson AG, Pandolfi PP. A continuum model for tumour suppression. Nature. 2011; 476:163-9. [PubMed: 21833082]

15. Toyooka S, Mitsudomi T, Soh J, Aokage K, Yamane M, Oto T, et al. Molecular oncology of lung cancer. General thoracic and cardiovascular surgery. 2011; 59:527-37. [PubMed: 21850578]

16. Fischer JR, Ohnmacht U, Rieger N, Zemaitis M, Stoffregen C, Manegold C, et al. Prognostic significance of RASSF1A promoter methylation on survival of non-small cell lung cancer patients treated with gemcitabine. Lung cancer. 2007; 56:115-23. [PubMed: 17196704]

17. Topaloglu O, Hoque MO, Tokumaru Y, Lee J, Ratovitski E, Sidransky D, et al. Detection of promoter hypermethylation of multiple genes in the tumor and bronchoalveolar lavage of patients with lung cancer. Clinical cancer research : an official journal of the American Association for Cancer Research. 2004; 10:2284-8. [PubMed: 15073103]

18. Belinsky SA, Nikula KJ, Palmisano WA, Michels R, Saccomanno G, Gabrielson E, et al. Aberrant methylation of p16(INK4a) is an early event in lung cancer and a potential biomarker for early diagnosis. Proceedings of the National Academy of Sciences of the United States of America. 1998; 95:11891-6. [PubMed: 9751761]

19. Nuovo GJ, Plaia TW, Belinsky SA, Baylin SB, Herman JG. In situ detection of the hypermethylation-induced inactivation of the p16 gene as an early event in oncogenesis. Proceedings of the National Academy of Sciences of the United States of America. 1999; 96:12754-9. [PubMed: 10535995]

20. Palmisano WA, Divine KK, Saccomanno G, Gilliland FD, Baylin SB, Herman JG, et al. Predicting lung cancer by detecting aberrant promoter methylation in sputum. Cancer research. 2000; 60:5954-8. [PubMed: 11085511]

21. Kim DH, Nelson HH, Wiencke JK, Zheng S, Christiani DC, Wain JC, et al. p16(INK4a) and histology-specific methylation of $\mathrm{CpG}$ islands by exposure to tobacco smoke in non-small cell lung cancer. Cancer research. 2001; 61:3419-24. [PubMed: 11309302]

22. Buckingham L, Penfield Faber L, Kim A, Liptay M, Barger C, Basu S, et al. PTEN, RASSF1 and DAPK site-specific hypermethylation and outcome in surgically treated stage I and II nonsmall 
cell lung cancer patients. International journal of cancer Journal international du cancer. 2010; 126:1630-9. [PubMed: 19795445]

23. Nakata S, Sugio K, Uramoto H, Oyama T, Hanagiri T, Morita M, et al. The methylation status and protein expression of $\mathrm{CDH} 1, \mathrm{p} 16$ (INK4A), and fragile histidine triad in nonsmall cell lung carcinoma: epigenetic silencing, clinical features, and prognostic significance. Cancer. 2006; 106:2190-9. [PubMed: 16598757]

24. Sterlacci W, Tzankov A, Veits L, Zelger B, Bihl MP, Foerster A, et al. A comprehensive analysis of p16 expression, gene status, and promoter hypermethylation in surgically resected non-small cell lung carcinomas. Journal of thoracic oncology : official publication of the International Association for the Study of Lung Cancer. 2011; 6:1649-57.

25. Tsou JA, Galler JS, Siegmund KD, Laird PW, Turla S, Cozen W, et al. Identification of a panel of sensitive and specific DNA methylation markers for lung adenocarcinoma. Molecular cancer. 2007; 6:70. [PubMed: 17967182]

26. Gasco M, Bell AK, Heath V, Sullivan A, Smith P, Hiller L, et al. Epigenetic inactivation of 14-3-3 sigma in oral carcinoma: association with p16(INK4a) silencing and human papillomavirus negativity. Cancer research. 2002; 62:2072-6. [PubMed: 11929827]

27. Kim DS, Cha SI, Lee JH, Lee YM, Choi JE, Kim MJ, et al. Aberrant DNA methylation profiles of non-small cell lung cancers in a Korean population. Lung cancer. 2007; 58:1-6. [PubMed: 17532092]

28. Shivapurkar N, Stastny V, Suzuki M, Wistuba, Li L, Zheng Y, et al. Application of a methylation gene panel by quantitative PCR for lung cancers. Cancer letters. 2007; 247:56-71. [PubMed: 16644104]

29. Tang X, Khuri FR, Lee JJ, Kemp BL, Liu D, Hong WK, et al. Hypermethylation of the deathassociated protein (DAP) kinase promoter and aggressiveness in stage I non-small-cell lung cancer. Journal of the National Cancer Institute. 2000; 92:1511-6. [PubMed: 10995806]

30. Dammann R, Strunnikova M, Schagdarsurengin U, Rastetter M, Papritz M, Hattenhorst UE, et al. $\mathrm{CpG}$ island methylation and expression of tumour-associated genes in lung carcinoma. European journal of cancer. 2005; 41:1223-36. [PubMed: 15911247]

31. Nelson HH, Marsit CJ, Christensen BC, Houseman EA, Kontic M, Wiemels JL, et al. Key epigenetic changes associated with lung cancer development: results from dense methylation array profiling. Epigenetics : official journal of the DNA Methylation Society. 2012; 7:559-66. [PubMed: 22522909]

32. Chen C, Yin N, Yin B, Lu Q. DNA methylation in thoracic neoplasms. Cancer letters. 2011; 301:7-16. [PubMed: 21087818]

33. Heller G, Zielinski CC, Zochbauer-Muller S. Lung cancer: from single-gene methylation to methylome profiling. Cancer metastasis reviews. 2010; 29:95-107. [PubMed: 20099008]

34. Li W, Deng J, Jiang P, Tang J. Association of 5'-CpG island hypermethylation of the FHIT gene with lung cancer in southern-central Chinese population. Cancer biology \& therapy. 2010; 10:9971000. [PubMed: 20814237]

35. Verri C, Roz L, Conte D, Liloglou T, Livio A, Vesin A, et al. Fragile histidine triad gene inactivation in lung cancer: the European Early Lung Cancer project. American journal of respiratory and critical care medicine. 2009; 179:396-401. [PubMed: 19096006]

36. Yanagawa N, Tamura G, Oizumi H, Kanauchi N, Endoh M, Sadahiro M, et al. Promoter hypermethylation of RASSF1A and RUNX3 genes as an independent prognostic prediction marker in surgically resected non-small cell lung cancers. Lung cancer. 2007; 58:131-8. [PubMed: 17606310]

37. Tomizawa Y, Iijima H, Nomoto T, Iwasaki Y, Otani Y, Tsuchiya S, et al. Clinicopathological significance of aberrant methylation of RARbeta2 at 3p24, RASSF1A at 3p21.3, and FHIT at 3p14.2 in patients with non-small cell lung cancer. Lung cancer. 2004; 46:305-12. [PubMed: 15541815]

38. Begum S, Brait M, Dasgupta S, Ostrow KL, Zahurak M, Carvalho AL, et al. An epigenetic marker panel for detection of lung cancer using cell-free serum DNA. Clinical cancer research : an official journal of the American Association for Cancer Research. 2011; 17:4494-503. [PubMed: 21610147] 
39. Grote HJ, Schmiemann V, Kiel S, Bocking A, Kappes R, Gabbert HE, et al. Aberrant methylation of the adenomatous polyposis coli promoter $1 \mathrm{~A}$ in bronchial aspirates from patients with suspected lung cancer. International journal of cancer Journal international du cancer. 2004; 110:751-5. [PubMed: 15146565]

40. Toyooka S, Maruyama R, Toyooka KO, McLerran D, Feng Z, Fukuyama Y, et al. Smoke exposure, histologic type and geography-related differences in the methylation profiles of nonsmall cell lung cancer. International journal of cancer Journal international du cancer. 2003; 103:153-60. [PubMed: 12455028]

41. Brabender J, Usadel H, Danenberg KD, Metzger R, Schneider PM, Lord RV, et al. Adenomatous polyposis coli gene promoter hypermethylation in non-small cell lung cancer is associated with survival. Oncogene. 2001; 20:3528-32. [PubMed: 11429699]

42. Ji M, Guan H, Gao C, Shi B, Hou P. Highly frequent promoter methylation and PIK3CA amplification in non-small cell lung cancer (NSCLC). BMC cancer. 2011; 11:147. [PubMed: 21507233]

43. Lee SM, Lee WK, Kim DS, Park JY. Quantitative promoter hypermethylation analysis of RASSF1A in lung cancer: comparison with methylation-specific PCR technique and clinical significance. Molecular medicine reports. 2012; 5:239-44. [PubMed: 21971684]

44. Niklinska W, Naumnik W, Sulewska A, Kozlowski M, Pankiewicz W, Milewski R. Prognostic significance of DAPK and RASSF1A promoter hypermethylation in non-small cell lung cancer (NSCLC). Folia histochemica et cytobiologica / Polish Academy of Sciences, Polish Histochemical and Cytochemical Society. 2009; 47:275-80.

45. Dammann R, Takahashi T, Pfeifer GP. The CpG island of the novel tumor suppressor gene RASSF1A is intensely methylated in primary small cell lung carcinomas. Oncogene. 2001; 20:3563-7. [PubMed: 11429703]

46. Kim DH, Nelson HH, Wiencke JK, Christiani DC, Wain JC, Mark EJ, et al. Promoter methylation of DAP-kinase: association with advanced stage in non-small cell lung cancer. Oncogene. 2001; 20:1765-70. [PubMed: 11313923]

47. Virmani AK, Rathi A, Zochbauer-Muller S, Sacchi N, Fukuyama Y, Bryant D, et al. Promoter methylation and silencing of the retinoic acid receptor-beta gene in lung carcinomas. Journal of the National Cancer Institute. 2000; 92:1303-7. [PubMed: 10944551]

48. Ekim M, Caner V, Buyukpinarbasili N, Tepeli E, Elmas L, Bagci G. Determination of O(6)methylguanine DNA methyltransferase promoter methylation in non-small cell lung cancer. Genetic testing and molecular biomarkers. 2011; 15:357-60. [PubMed: 21288129]

49. Lai JC, Cheng YW, Goan YG, Chang JT, Wu TC, Chen CY, et al. Promoter methylation of O(6)methylguanine-DNA-methyltransferase in lung cancer is regulated by p53. DNA repair. 2008; 7:1352-63. [PubMed: 18555750]

50. Brabender J, Usadel H, Metzger R, Schneider PM, Park J, Salonga D, et al. Quantitative O(6)methylguanine DNA methyltransferase methylation analysis in curatively resected non-small cell lung cancer: associations with clinical outcome. Clinical cancer research : an official journal of the American Association for Cancer Research. 2003; 9:223-7. [PubMed: 12538473]

51. Schmidt B, Liebenberg V, Dietrich D, Schlegel T, Kneip C, Seegebarth A, et al. SHOX2 DNA methylation is a biomarker for the diagnosis of lung cancer based on bronchial aspirates. BMC cancer. 2010; 10:600. [PubMed: 21047392]

52. Schneider KU, Dietrich D, Fleischhacker M, Leschber G, Merk J, Schaper F, et al. Correlation of SHOX2 gene amplification and DNA methylation in lung cancer tumors. BMC cancer. 2011; 11:102. [PubMed: 21426551]

53. Yu GP, Ji Y, Chen GQ, Huang B, Shen K, Wu S, et al. Application of RUNX3 gene promoter methylation in the diagnosis of non-small cell lung cancer. Oncology letters. 2012; 3:159-62. [PubMed: 22740873]

54. Omar MF, Ito K, Nga ME, Soo R, Peh BK, Ismail TM, et al. RUNX3 downregulation in human lung adenocarcinoma is independent of p53, EGFR or KRAS status. Pathology oncology research : POR. 2012; 18:783-92. [PubMed: 22729835]

55. Sato K, Tomizawa Y, Iijima H, Saito R, Ishizuka T, Nakajima T, et al. Epigenetic inactivation of the RUNX3 gene in lung cancer. Oncology reports. 2006; 15:129-35. [PubMed: 16328045] 
56. Kim TY, Lee HJ, Hwang KS, Lee M, Kim JW, Bang YJ, et al. Methylation of RUNX3 in various types of human cancers and premalignant stages of gastric carcinoma. Laboratory investigation; a journal of technical methods and pathology. 2004; 84:479-84.

57. Li QL, Kim HR, Kim WJ, Choi JK, Lee YH, Kim HM, et al. Transcriptional silencing of the RUNX3 gene by CpG hypermethylation is associated with lung cancer. Biochemical and biophysical research communications. 2004; 314:223-8. [PubMed: 14715269]

58. Kim DS, Kim MJ, Lee JY, Kim YZ, Kim EJ, Park JY. Aberrant methylation of E-cadherin and Hcadherin genes in nonsmall cell lung cancer and its relation to clinicopathologic features. Cancer. 2007; 110:2785-92. [PubMed: 17960794]

59. Heller G, Fong KM, Girard L, Seidl S, End-Pfutzenreuter A, Lang G, et al. Expression and methylation pattern of TSLC1 cascade genes in lung carcinomas. Oncogene. 2006; 25:959-68. [PubMed: 16205641]

60. Kikuchi S, Yamada D, Fukami T, Maruyama T, Ito A, Asamura H, et al. Hypermethylation of the TSLC1/IGSF4 promoter is associated with tobacco smoking and a poor prognosis in primary nonsmall cell lung carcinoma. Cancer. 2006; 106:1751-8. [PubMed: 16534787]

61. Fukami T, Fukuhara H, Kuramochi M, Maruyama T, Isogai K, Sakamoto M, et al. Promoter methylation of the TSLC1 gene in advanced lung tumors and various cancer cell lines. International journal of cancer Journal international du cancer. 2003; 107:53-9. [PubMed: 12925956]

62. Ramirez JL, Sarries C, de Castro PL, Roig B, Queralt C, Escuin D, et al. Methylation patterns and K-ras mutations in tumor and paired serum of resected non-small-cell lung cancer patients. Cancer letters. 2003; 193:207-16. [PubMed: 12706879]

63. Virmani A, Rathi A, Sugio K, Sathyanarayana UG, Toyooka S, Kischel FC, et al. Aberrant methylation of TMS1 in small cell, non small cell lung cancer and breast cancer. International journal of cancer Journal international du cancer. 2003; 106:198-204. [PubMed: 12800194]

64. Kikuchi S, Yamada D, Fukami T, Masuda M, Sakurai-Yageta M, Williams YN, et al. Promoter methylation of DAL-1/4.1B predicts poor prognosis in non-small cell lung cancer. Clinical cancer research : an official journal of the American Association for Cancer Research. 2005; 11:2954-61. [PubMed: 15837747]

65. Marsit CJ, Zheng S, Aldape K, Hinds PW, Nelson HH, Wiencke JK, et al. PTEN expression in non-small-cell lung cancer: evaluating its relation to tumor characteristics, allelic loss, and epigenetic alteration. Human pathology. 2005; 36:768-76. [PubMed: 16084946]

66. Soria JC, Lee HY, Lee JI, Wang L, Issa JP, Kemp BL, et al. Lack of PTEN expression in nonsmall cell lung cancer could be related to promoter methylation. Clinical cancer research : an official journal of the American Association for Cancer Research. 2002; 8:1178-84. [PubMed: 12006535]

67. Grimminger PP, Maus MK, Schneider PM, Metzger R, Holscher AH, Sugita H, et al. Glutathione S-transferase PI (GST-PI) mRNA expression and DNA methylation is involved in the pathogenesis and prognosis of NSCLC. Lung cancer. 2012; 78:87-91. [PubMed: 22884253]

68. Vallbohmer D, Brabender J, Yang D, Schneider PM, Metzger R, Danenberg KD, et al. DNA methyltransferases messenger RNA expression and aberrant methylation of $\mathrm{CpG}$ islands in nonsmall-cell lung cancer: association and prognostic value. Clinical lung cancer. 2006; 8:39-44. [PubMed: 16870044]

69. Belinsky SA. Silencing of genes by promoter hypermethylation: key event in rodent and human lung cancer. Carcinogenesis. 2005; 26:1481-7. [PubMed: 15661809]

70. Lin Q, Geng J, Ma K, Yu J, Sun J, Shen Z, et al. RASSF1A, APC, ESR1, ABCB1 and HOXC9, but not p16INK4A, DAPK1, PTEN and MT1G genes were frequently methylated in the stage I non-small cell lung cancer in China. Journal of cancer research and clinical oncology. 2009; 135:1675-84. [PubMed: 19506903]

71. Rauch T, Wang Z, Zhang X, Zhong X, Wu X, Lau SK, et al. Homeobox gene methylation in lung cancer studied by genome-wide analysis with a microarray-based methylated $\mathrm{CpG}$ island recovery assay. Proceedings of the National Academy of Sciences of the United States of America. 2007; 104:5527-32. [PubMed: 17369352] 
72. Yano M, Toyooka S, Tsukuda K, Dote H, Ouchida M, Hanabata T, et al. Aberrant promoter methylation of human DAB2 interactive protein (hDAB2IP) gene in lung cancers. International journal of cancer Journal international du cancer. 2005; 113:59-66. [PubMed: 15386433]

73. Chen H, Suzuki M, Nakamura Y, Ohira M, Ando S, Iida T, et al. Aberrant methylation of FBN2 in human non-small cell lung cancer. Lung cancer. 2005; 50:43-9. [PubMed: 15951052]

74. Liu Z, Li W, Lei Z, Zhao J, Chen XF, Liu R, et al. CpG island methylator phenotype involving chromosome $3 p$ confers an increased risk of non-small cell lung cancer. Journal of thoracic oncology : official publication of the International Association for the Study of Lung Cancer. 2010; 5:790-7.

75. Liu Z, Zhao J, Chen XF, Li W, Liu R, Lei Z, et al. CpG island methylator phenotype involving tumor suppressor genes located on chromosome $3 p$ in non-small cell lung cancer. Lung cancer. 2008; 62:15-22. [PubMed: 18358560]

76. Marsit CJ, Houseman EA, Christensen BC, Eddy K, Bueno R, Sugarbaker DJ, et al. Examination of a $\mathrm{CpG}$ island methylator phenotype and implications of methylation profiles in solid tumors. Cancer research. 2006; 66:10621-9. [PubMed: 17079487]

77. Shinjo K, Okamoto Y, An B, Yokoyama T, Takeuchi I, Fujii M, et al. Integrated analysis of genetic and epigenetic alterations reveals $\mathrm{CpG}$ island methylator phenotype associated with distinct clinical characters of lung adenocarcinoma. Carcinogenesis. 2012; 33:1277-85. [PubMed: 22532250]

78. Kim H, Kwon YM, Kim JS, Han J, Shim YM, Park J, et al. Elevated mRNA levels of DNA methyltransferase-1 as an independent prognostic factor in primary nonsmall cell lung cancer. Cancer. 2006; 107:1042-9. [PubMed: 16888795]

79. Lin RK, Hsu HS, Chang JW, Chen CY, Chen JT, Wang YC. Alteration of DNA methyltransferases contributes to $5^{\prime} \mathrm{CpG}$ methylation and poor prognosis in lung cancer. Lung cancer. 2007; 55:20513. [PubMed: 17140695]

80. Anisowicz A, Huang H, Braunschweiger KI, Liu Z, Giese H, Wang H, et al. A high-throughput and sensitive method to measure global DNA methylation: application in lung cancer. BMC cancer. 2008; 8:222. [PubMed: 18673580]

81. Daskalos A, Logotheti S, Markopoulou S, Xinarianos G, Gosney JR, Kastania AN, et al. Global DNA hypomethylation-induced DeltaNp73 transcriptional activation in non-small cell lung cancer. Cancer letters. 2011; 300:79-86. [PubMed: 20926182]

82. Feinberg AP, Vogelstein B. Hypomethylation of ras oncogenes in primary human cancers. Biochemical and biophysical research communications. 1983; 111:47-54. [PubMed: 6187346]

83. Feinberg AP, Vogelstein B. Hypomethylation distinguishes genes of some human cancers from their normal counterparts. Nature. 1983; 301:89-92. [PubMed: 6185846]

84. Kondo M, Suzuki H, Ueda R, Osada H, Takagi K, Takahashi T, et al. Frequent loss of imprinting of the $\mathrm{H} 19$ gene is often associated with its overexpression in human lung cancers. Oncogene. 1995; 10:1193-8. [PubMed: 7700644]

85. Rauch TA, Zhong X, Wu X, Wang M, Kernstine KH, Wang Z, et al. High-resolution mapping of DNA hypermethylation and hypomethylation in lung cancer. Proceedings of the National Academy of Sciences of the United States of America. 2008; 105:252-7. [PubMed: 18162535]

86. Glazer CA, Smith IM, Ochs MF, Begum S, Westra W, Chang SS, et al. Integrative discovery of epigenetically derepressed cancer testis antigens in NSCLC. PloS one. 2009; 4:e8189. [PubMed: 19997593]

87. Kim SH, Lee S, Lee CH, Lee MK, Kim YD, Shin DH, et al. Expression of cancer-testis antigens MAGE-A3/6 and NY-ESO-1 in non-small-cell lung carcinomas and their relationship with immune cell infiltration. Lung. 2009; 187:401-11. [PubMed: 19795170]

88. Kayser G, Sienel W, Kubitz B, Mattern D, Stickeler E, Passlick B, et al. Poor outcome in primary non-small cell lung cancers is predicted by transketolase TKTL1 expression. Pathology. 2011; 43:719-24. [PubMed: 22027741]

89. Renaud S, Pugacheva EM, Delgado MD, Braunschweig R, Abdullaev Z, Loukinov D, et al. Expression of the CTCF-paralogous cancer-testis gene, brother of the regulator of imprinted sites (BORIS), is regulated by three alternative promoters modulated by $\mathrm{CpG}$ methylation and by CTCF and p53 transcription factors. Nucleic acids research. 2007; 35:7372-88. [PubMed: 17962299] 
90. Hong JA, Kang Y, Abdullaev Z, Flanagan PT, Pack SD, Fischette MR, et al. Reciprocal binding of CTCF and BORIS to the NY-ESO-1 promoter coincides with derepression of this cancer-testis gene in lung cancer cells. Cancer research. 2005; 65:7763-74. [PubMed: 16140944]

91. Radhakrishnan VM, Jensen TJ, Cui H, Futscher BW, Martinez JD. Hypomethylation of the 14-3-3sigma promoter leads to increased expression in non-small cell lung cancer. Genes, chromosomes \& cancer. 2011; 50:830-6. [PubMed: 21755566]

92. Shiba-Ishii A, Noguchi M. Aberrant stratifin overexpression is regulated by tumor-associated CpG demethylation in lung adenocarcinoma. The American journal of pathology. 2012; 180:1653-62. [PubMed: 22310466]

93. Gu Y, Wang C, Wang Y, Qiu X, Wang E. Expression of thymosin beta10 and its role in non-small cell lung cancer. Human pathology. 2009; 40:117-24. [PubMed: 18789485]

94. Jang SJ, Soria JC, Wang L, Hassan KA, Morice RC, Walsh GL, et al. Activation of melanoma antigen tumor antigens occurs early in lung carcinogenesis. Cancer research. 2001; 61:7959-63. [PubMed: 11691819]

95. Gronbaek K, Hother C, Jones PA. Epigenetic changes in cancer. Apmis. 2007; 115:1039-59. [PubMed: 18042143]

96. Rideout WM 3rd, Coetzee GA, Olumi AF, Jones PA. 5-Methylcytosine as an endogenous mutagen in the human LDL receptor and p53 genes. Science (New York, NY. 1990; 249:1288-90.

97. Chen JX, Zheng Y, West M, Tang MS. Carcinogens preferentially bind at methylated CpG in the p53 mutational hot spots. Cancer research. 1998; 58:2070-5. [PubMed: 9605744]

98. Denissenko MF, Pao A, Tang M, Pfeifer GP. Preferential formation of benzo [a]pyrene adducts at lung cancer mutational hotspots in P53. Science (New York, NY. 1996; 274:430-2.

99. Yoon JH, Smith LE, Feng Z, Tang M, Lee CS, Pfeifer GP. Methylated CpG dinucleotides are the preferential targets for G-to-T transversion mutations induced by benzo [a]pyrene diol epoxide in mammalian cells: similarities with the p53 mutation spectrum in smoking-associated lung cancers. Cancer research. 2001; 61:7110-7. [PubMed: 11585742]

100. Feng Z, Hu W, Hu Y, Tang MS. Acrolein is a major cigarette-related lung cancer agent: Preferential binding at 553 mutational hotspots and inhibition of DNA repair. Proceedings of the National Academy of Sciences of the United States of America. 2006; 103:15404-9. [PubMed: 17030796]

101. Sasaki H, Moriyama S, Nakashima Y, Kobayashi Y, Kiriyama M, Fukai I, et al. Histone deacetylase 1 mRNA expression in lung cancer. Lung cancer. 2004; 46:171-8. [PubMed: 15474665]

102. Nakagawa M, Oda Y, Eguchi T, Aishima S, Yao T, Hosoi F, et al. Expression profile of class I histone deacetylases in human cancer tissues. Oncology reports. 2007; 18:769-74. [PubMed: 17786334]

103. Bartling B, Hofmann HS, Boettger T, Hansen G, Burdach S, Silber RE, et al. Comparative application of antibody and gene array for expression profiling in human squamous cell lung carcinoma. Lung cancer. 2005; 49:145-54. [PubMed: 16022908]

104. Esteller M. Epigenetics in cancer. The New England journal of medicine. 2008; 358:1148-59. [PubMed: 18337604]

105. Suzuki H, Ouchida M, Yamamoto H, Yano M, Toyooka S, Aoe M, et al. Decreased expression of the SIN3A gene, a candidate tumor suppressor located at the prevalent allelic loss region $15 \mathrm{q} 23$ in non-small cell lung cancer. Lung cancer. 2008; 59:24-31. [PubMed: 17854949]

106. Van Den Broeck A, Brambilla E, Moro-Sibilot D, Lantuejoul S, Brambilla C, Eymin B, et al. Loss of histone H4K20 trimethylation occurs in preneoplasia and influences prognosis of nonsmall cell lung cancer. Clinical cancer research : an official journal of the American Association for Cancer Research. 2008; 14:7237-45. [PubMed: 18974389]

107. Hu J, Liu YL, Piao SL, Yang DD, Yang YM, Cai L. Expression patterns of USP22 and potential targets BMI-1, PTEN, p-AKT in non-small-cell lung cancer. Lung cancer. 2012; 77:593-9. [PubMed: 22717106]

108. Huang J, Qiu Y, Chen G, Huang L, He J. The relationship between Bmi-1 and the epithelialmesenchymal transition in lung squamous cell carcinoma. Medical oncology. 2012; 29:1606-13. [PubMed: 21656027] 
109. Kimura M, Takenobu H, Akita N, Nakazawa A, Ochiai H, Shimozato O, et al. Bmi1 regulates cell fate via tumor suppressor WWOX repression in small-cell lung cancer cells. Cancer science. 2011; 102:983-90. [PubMed: 21276135]

110. Vonlanthen S, Heighway J, Altermatt HJ, Gugger M, Kappeler A, Borner MM, et al. The bmi-1 oncoprotein is differentially expressed in non-small cell lung cancer and correlates with INK4AARF locus expression. British journal of cancer. 2001; 84:1372-6. [PubMed: 11355949]

111. Breuer RH, Snijders PJ, Smit EF, Sutedja TG, Sewalt RG, Otte AP, et al. Increased expression of the EZH2 polycomb group gene in BMI-1-positive neoplastic cells during bronchial carcinogenesis. Neoplasia. 2004; 6:736-43. [PubMed: 15720799]

112. Cao W, de Ribeiro RO, Liu D, Saintigny P, Xia R, Xue Y, et al. EZH2 promotes malignant behaviors via cell cycle dysregulation and its mRNA level associates with prognosis of patient with non-small cell lung cancer. PloS one. 2012; 7:e52984. [PubMed: 23300840]

113. Takawa M, Masuda K, Kunizaki M, Daigo Y, Takagi K, Iwai Y, et al. Validation of the histone methyltransferase EZH2 as a therapeutic target for various types of human cancer and as a prognostic marker. Cancer science. 2011; 102:1298-305. [PubMed: 21539681]

114. Wan L, Li X, Shen H, Bai X. Quantitative analysis of EZH2 expression and its correlations with lung cancer patients' clinical pathological characteristics. Clinical \& translational oncology : official publication of the Federation of Spanish Oncology Societies and of the National Cancer Institute of Mexico. 2013; 15:132-8.

115. Zhou Y, Wan C, Liu Y, Lv L, Chen B, Ni R, et al. Polycomb Group Oncogene RING1 is Overexpressed in Non-Small Cell Lung Cancer. Pathology oncology research : POR. 2014

116. Sato T, Kaneda A, Tsuji S, Isagawa T, Yamamoto S, Fujita T, et al. PRC2 overexpression and PRC2-target gene repression relating to poorer prognosis in small cell lung cancer. Scientific reports. 2013; 3:1911. [PubMed: 23714854]

117. Lv Y, Yuan C, Xiao X, Wang X, Ji X, Yu H, et al. The expression and significance of the enhancer of zeste homolog 2 in lung adenocarcinoma. Oncology reports. 2012; 28:147-54. [PubMed: 22552406]

118. Huqun, Ishikawa R, Zhang J, Miyazawa H, Goto Y, Shimizu Y, et al. Enhancer of zeste homolog 2 is a novel prognostic biomarker in nonsmall cell lung cancer. Cancer. 2012; 118:1599-606. [PubMed: 21837672]

119. Crea F, Paolicchi E, Marquez VE, Danesi R. Polycomb genes and cancer: time for clinical application? Critical reviews in oncology/hematology. 2012; 83:184-93. [PubMed: 22112692]

120. Koch LK, Zhou H, Ellinger J, Biermann K, Holler T, von Rucker A, et al. Stem cell marker expression in small cell lung carcinoma and developing lung tissue. Human pathology. 2008; 39:1597-605. [PubMed: 18656241]

121. Vrzalikova K, Skarda J, Ehrmann J, Murray PG, Fridman E, Kopolovic J, et al. Prognostic value of Bmi-1 oncoprotein expression in NSCLC patients: a tissue microarray study. Journal of cancer research and clinical oncology. 2008; 134:1037-42. [PubMed: 18264721]

122. Dovey JS, Zacharek SJ, Kim CF, Lees JA. Bmi1 is critical for lung tumorigenesis and bronchioalveolar stem cell expansion. Proceedings of the National Academy of Sciences of the United States of America. 2008; 105:11857-62. [PubMed: 18697930]

123. Liu L, Andrews LG, Tollefsbol TO. Loss of the human polycomb group protein BMI1 promotes cancer-specific cell death. Oncogene. 2006; 25:4370-5. [PubMed: 16501599]

124. Guan P, Yin Z, Li X, Wu W, Zhou B. Meta-analysis of human lung cancer microRNA expression profiling studies comparing cancer tissues with normal tissues. Journal of experimental \& clinical cancer research : CR. 2012; 31:54. [PubMed: 22672859]

125. Vosa U, Vooder T, Kolde R, Vilo J, Metspalu A, Annilo T. Meta-analysis of microRNA expression in lung cancer. International journal of cancer Journal international du cancer. 2013; 132:2884-93. [PubMed: 23225545]

126. Shi X, Sun M, Liu H, Yao Y, Song Y. Long non-coding RNAs: a new frontier in the study of human diseases. Cancer letters. 2013; 339:159-66. [PubMed: 23791884]

127. Gutschner T, Hammerle M, Diederichs S. MALAT1 -- a paradigm for long noncoding RNA function in cancer. Journal of molecular medicine. 2013; 91:791-801. [PubMed: 23529762] 
128. Ji P, Diederichs S, Wang W, Boing S, Metzger R, Schneider PM, et al. MALAT-1, a novel noncoding RNA, and thymosin beta4 predict metastasis and survival in early-stage non-small cell lung cancer. Oncogene. 2003; 22:8031-41. [PubMed: 12970751]

129. Schmidt LH, Spieker T, Koschmieder S, Schaffers S, Humberg J, Jungen D, et al. The long noncoding MALAT-1 RNA indicates a poor prognosis in non-small cell lung cancer and induces migration and tumor growth. Journal of thoracic oncology : official publication of the International Association for the Study of Lung Cancer. 2011; 6:1984-92.

130. Gutschner T, Hammerle M, Eissmann M, Hsu J, Kim Y, Hung G, et al. The noncoding RNA MALAT1 is a critical regulator of the metastasis phenotype of lung cancer cells. Cancer research. 2013; 73:1180-9. [PubMed: 23243023]

131. Tano K, Mizuno R, Okada T, Rakwal R, Shibato J, Masuo Y, et al. MALAT-1 enhances cell motility of lung adenocarcinoma cells by influencing the expression of motility-related genes. FEBS letters. 2010; 584:4575-80. [PubMed: 20937273]

132. Gutschner T, Baas M, Diederichs S. Noncoding RNA gene silencing through genomic integration of RNA destabilizing elements using zinc finger nucleases. Genome research. 2011; 21:1944-54. [PubMed: 21844124]

133. Liu XH, Liu ZL, Sun M, Liu J, Wang ZX, De W. The long non-coding RNA HOTAIR indicates a poor prognosis and promotes metastasis in non-small cell lung cancer. BMC cancer. 2013; 13:464. [PubMed: 24103700]

134. Nakagawa T, Endo H, Yokoyama M, Abe J, Tamai K, Tanaka N, et al. Large noncoding RNA HOTAIR enhances aggressive biological behavior and is associated with short disease-free survival in human non-small cell lung cancer. Biochemical and biophysical research communications. 2013; 436:319-24. [PubMed: 23743197]

135. Zhuang Y, Wang X, Nguyen HT, Zhuo Y, Cui X, Fewell C, et al. Induction of long intergenic non-coding RNA HOTAIR in lung cancer cells by type I collagen. Journal of hematology \& oncology. 2013; 6:35. [PubMed: 23668363]

136. Lujambio A, Ropero S, Ballestar E, Fraga MF, Cerrato C, Setien F, et al. Genetic unmasking of an epigenetically silenced microRNA in human cancer cells. Cancer research. 2007; 67:1424-9. [PubMed: 17308079]

137. Wang Z, Chen Z, Gao Y, Li N, Li B, Tan F, et al. DNA hypermethylation of microRNA-34b/c has prognostic value for stage non-small cell lung cancer. Cancer biology \& therapy. 2011; 11:490-6. [PubMed: 21383543]

138. Nadal E, Chen G, Gallegos M, Lin L, Ferrer-Torres D, Truini A, et al. Epigenetic Inactivation of microRNA-34b/c Predicts Poor Disease-Free Survival in Early-Stage Lung Adenocarcinoma. Clinical cancer research : an official journal of the American Association for Cancer Research. 2013

139. Cao J, Song Y, Bi N, Shen J, Liu W, Fan J, et al. DNA methylation-mediated repression of miR-886-3p predicts poor outcome of human small cell lung cancer. Cancer research. 2013; 73:3326-35. [PubMed: 23592755]

140. Heller G, Weinzierl M, Noll C, Babinsky V, Ziegler B, Altenberger C, et al. Genome-wide miRNA expression profiling identifies miR-9-3 and miR-193a as targets for DNA methylation in non-small cell lung cancers. Clinical cancer research : an official journal of the American Association for Cancer Research. 2012; 18:1619-29. [PubMed: 22282464]

141. Brueckner B, Stresemann C, Kuner R, Mund C, Musch T, Meister M, et al. The human let-7a-3 locus contains an epigenetically regulated microRNA gene with oncogenic function. Cancer research. 2007; 67:1419-23. [PubMed: 17308078]

142. Fabbri M, Garzon R, Cimmino A, Liu Z, Zanesi N, Callegari E, et al. MicroRNA-29 family reverts aberrant methylation in lung cancer by targeting DNA methyltransferases 3A and 3B. Proceedings of the National Academy of Sciences of the United States of America. 2007; 104:15805-10. [PubMed: 17890317]

143. Feng Q, Hawes SE, Stern JE, Wiens L, Lu H, Dong ZM, et al. DNA methylation in tumor and matched normal tissues from non-small cell lung cancer patients. Cancer epidemiology, biomarkers \& prevention : a publication of the American Association for Cancer Research, cosponsored by the American Society of Preventive Oncology. 2008; 17:645-54. 
144. Toyooka S, Suzuki M, Tsuda T, Toyooka KO, Maruyama R, Tsukuda K, et al. Dose effect of smoking on aberrant methylation in non-small cell lung cancers. International journal of cancer Journal international du cancer. 2004; 110:462-4. [PubMed: 15095316]

145. Kim H, Kwon YM, Kim JS, Lee H, Park JH, Shim YM, et al. Tumor-specific methylation in bronchial lavage for the early detection of non-small-cell lung cancer. Journal of clinical oncology : official journal of the American Society of Clinical Oncology. 2004; 22:2363-70. [PubMed: 15197197]

146. Liu Y, Lan Q, Siegfried JM, Luketich JD, Keohavong P. Aberrant promoter methylation of p16 and MGMT genes in lung tumors from smoking and never-smoking lung cancer patients. Neoplasia. 2006; 8:46-51. [PubMed: 16533425]

147. Vaissiere T, Hung RJ, Zaridze D, Moukeria A, Cuenin C, Fasolo V, et al. Quantitative analysis of DNA methylation profiles in lung cancer identifies aberrant DNA methylation of specific genes and its association with gender and cancer risk factors. Cancer research. 2009; 69:243-52. [PubMed: 19118009]

148. Yanagawa N, Tamura G, Oizumi H, Endoh M, Sadahiro M, Motoyama T. Inverse correlation between EGFR mutation and FHIT, RASSF1A and RUNX3 methylation in lung adenocarcinoma: relation with smoking status. Anticancer research. 2011; 31:1211-4. [PubMed: 21508367]

149. Hong YS, Roh MS, Kim NY, Lee HJ, Kim HK, Lee KE, et al. Hypermethylation of p16INK4a in Korean non-small cell lung cancer patients. Journal of Korean medical science. 2007; 22 (Suppl):S32-7. [PubMed: 17923752]

150. Andujar P, Wang J, Descatha A, Galateau-Salle F, Abd-Alsamad I, Billon-Galland MA, et al. p16INK4A inactivation mechanisms in non-small-cell lung cancer patients occupationally exposed to asbestos. Lung cancer. 2010; 67:23-30. [PubMed: 19375815]

151. Liu F, Killian JK, Yang M, Walker RL, Hong JA, Zhang M, et al. Epigenomic alterations and gene expression profiles in respiratory epithelia exposed to cigarette smoke condensate. Oncogene. 2010; 29:3650-64. [PubMed: 20440268]

152. Marwick JA, Kirkham PA, Stevenson CS, Danahay H, Giddings J, Butler K, et al. Cigarette smoke alters chromatin remodeling and induces proinflammatory genes in rat lungs. American journal of respiratory cell and molecular biology. 2004; 31:633-42. [PubMed: 15333327]

153. Kaira K, Sunaga N, Tomizawa Y, Yanagitani N, Ishizuka T, Saito R, et al. Epigenetic inactivation of the RAS-effector gene RASSF2 in lung cancers. International journal of oncology. 2007; 31:169-73. [PubMed: 17549418]

154. Tessema M, Yu YY, Stidley CA, Machida EO, Schuebel KE, Baylin SB, et al. Concomitant promoter methylation of multiple genes in lung adenocarcinomas from current, former and never smokers. Carcinogenesis. 2009; 30:1132-8. [PubMed: 19435948]

155. Lin RK, Hsieh YS, Lin P, Hsu HS, Chen CY, Tang YA, et al. The tobacco-specific carcinogen NNK induces DNA methyltransferase 1 accumulation and tumor suppressor gene hypermethylation in mice and lung cancer patients. The Journal of clinical investigation. 2010; 120:521-32. [PubMed: 20093774]

156. Damiani LA, Yingling CM, Leng S, Romo PE, Nakamura J, Belinsky SA. Carcinogen-induced gene promoter hypermethylation is mediated by DNMT1 and causal for transformation of immortalized bronchial epithelial cells. Cancer research. 2008; 68:9005-14. [PubMed: 18974146]

157. Wang J, Xu Y, Li J, Sun X, Wang LP, Ji WY. The tobacco-specific carcinogen NNK induces DNA methyltransferase 1 accumulation in laryngeal carcinoma. Oral oncology. 2012; 48:541-6. [PubMed: 22317856]

158. Wang J, Zhao SL, Li Y, Meng M, Qin CY. 4-(Methylnitrosamino)-1-(3-pyridyl)-1-butanone induces retinoic acid receptor beta hypermethylation through DNA methyltransferase 1 accumulation in esophageal squamous epithelial cells. Asian Pacific journal of cancer prevention : APJCP. 2012; 13:2207-12. [PubMed: 22901195]

159. Hutt JA, Vuillemenot BR, Barr EB, Grimes MJ, Hahn FF, Hobbs CH, et al. Life-span inhalation exposure to mainstream cigarette smoke induces lung cancer in $\mathrm{B} 6 \mathrm{C} 3 \mathrm{~F} 1$ mice through genetic and epigenetic pathways. Carcinogenesis. 2005; 26:1999-2009. [PubMed: 15944214] 
160. Pulling LC, Vuillemenot BR, Hutt JA, Devereux TR, Belinsky SA. Aberrant promoter hypermethylation of the death-associated protein kinase gene is early and frequent in murine lung tumors induced by cigarette smoke and tobacco carcinogens. Cancer research. 2004; 64:3844-8. [PubMed: 15172992]

161. Vuillemenot BR, Hutt JA, Belinsky SA. Gene promoter hypermethylation in mouse lung tumors. Molecular cancer research : MCR. 2006; 4:267-73. [PubMed: 16603640]

162. Balkwill F, Coussens LM. Cancer: an inflammatory link. Nature. 2004; 431:405-6. [PubMed: 15385993]

163. Coussens LM, Werb Z. Inflammation and cancer. Nature. 2002; 420:860-7. [PubMed: 12490959]

164. Meng X, Riordan NH. Cancer is a functional repair tissue. Medical hypotheses. 2006; 66:486-90. [PubMed: 16290925]

165. O'Hagan HM, Wang W, Sen S, Destefano Shields C, Lee SS, Zhang YW, et al. Oxidative damage targets complexes containing DNA methyltransferases, SIRT1, and polycomb members to promoter CpG Islands. Cancer cell. 2011; 20:606-19. [PubMed: 22094255]

166. Northrop-Clewes CA, Thurnham DI. Monitoring micronutrients in cigarette smokers. Clinica chimica acta; international journal of clinical chemistry. 2007; 377:14-38.

167. Khaled MA, Krumdieck CL. Association of folate molecules as determined by proton NMR: implications on enzyme binding. Biochemical and biophysical research communications. 1985; 130:1273-80. [PubMed: 3839676]

168. Abu Khaled M, Watkins CL, Krumdieck CL. Inactivation of B12 and folate coenzymes by butyl nitrite as observed by NMR: implications on one-carbon transfer mechanism. Biochemical and biophysical research communications. 1986; 135:201-7. [PubMed: 3954771]

169. Ortega RM, Lopez-Sobaler AM, Gonzalez-Gross MM, Redondo RM, Marzana I, Zamora MJ, et al. Influence of smoking on folate intake and blood folate concentrations in a group of elderly Spanish men. Journal of the American College of Nutrition. 1994; 13:68-72. [PubMed: 8157858]

170. Piyathilake CJ, Macaluso M, Hine RJ, Richards EW, Krumdieck CL. Local and systemic effects of cigarette smoking on folate and vitamin B-12. The American journal of clinical nutrition. 1994; 60:559-66. [PubMed: 8092091]

171. Blount BC, Mack MM, Wehr CM, MacGregor JT, Hiatt RA, Wang G, et al. Folate deficiency causes uracil misincorporation into human DNA and chromosome breakage: implications for cancer and neuronal damage. Proceedings of the National Academy of Sciences of the United States of America. 1997; 94:3290-5. [PubMed: 9096386]

172. Fang JY, Xiao SD. Folic acid, polymorphism of methyl-group metabolism genes, and DNA methylation in relation to GI carcinogenesis. Journal of gastroenterology. 2003; 38:821-9. [PubMed: 14564626]

173. Cui FM, Li JX, Chen Q, Du HB, Zhang SY, Nie JH, et al. Radon-induced alterations in microRNA expression profiles in transformed BEAS2B cells. Journal of toxicology and environmental health Part A. 2013; 76:107-19. [PubMed: 23294299]

174. Su S, Jin Y, Zhang W, Yang L, Shen Y, Cao Y, et al. Aberrant promoter methylation of p16(INK4a) and O(6)-methylguanine-DNA methyltransferase genes in workers at a Chinese uranium mine. Journal of occupational health. 2006; 48:261-6. [PubMed: 16902270]

175. Pulling LC, Divine KK, Klinge DM, Gilliland FD, Kang T, Schwartz AG, et al. Promoter hypermethylation of the O6-methylguanine-DNA methyltransferase gene: more common in lung adenocarcinomas from never-smokers than smokers and associated with tumor progression. Cancer research. 2003; 63:4842-8. [PubMed: 12941804]

176. Johnson DH, Fehrenbacher L, Novotny WF, Herbst RS, Nemunaitis JJ, Jablons DM, et al. Randomized phase II trial comparing bevacizumab plus carboplatin and paclitaxel with carboplatin and paclitaxel alone in previously untreated locally advanced or metastatic nonsmall-cell lung cancer. Journal of clinical oncology : official journal of the American Society of Clinical Oncology. 2004; 22:2184-91. [PubMed: 15169807]

177. Sandler A, Gray R, Perry MC, Brahmer J, Schiller JH, Dowlati A, et al. Paclitaxel-carboplatin alone or with bevacizumab for non-small-cell lung cancer. The New England journal of medicine. 2006; 355:2542-50. [PubMed: 17167137] 
178. Reck M, von Pawel J, Zatloukal P, Ramlau R, Gorbounova V, Hirsh V, et al. Phase III trial of cisplatin plus gemcitabine with either placebo or bevacizumab as first-line therapy for nonsquamous non-small-cell lung cancer: AVAil. Journal of clinical oncology : official journal of the American Society of Clinical Oncology. 2009; 27:1227-34. [PubMed: 19188680]

179. Scagliotti G, Brodowicz T, Shepherd FA, Zielinski C, Vansteenkiste J, Manegold C, et al. Treatment-by-histology interaction analyses in three phase III trials show superiority of pemetrexed in nonsquamous non-small cell lung cancer. Journal of thoracic oncology : official publication of the International Association for the Study of Lung Cancer. 2011; 6:64-70.

180. Kwon YJ, Lee SJ, Koh JS, Kim SH, Lee HW, Kang MC, et al. Genome-wide analysis of DNA methylation and the gene expression change in lung cancer. Journal of thoracic oncology : official publication of the International Association for the Study of Lung Cancer. 2012; 7:20-33.

181. Castro M, Grau L, Puerta P, Gimenez L, Venditti J, Quadrelli S, et al. Multiplexed methylation profiles of tumor suppressor genes and clinical outcome in lung cancer. Journal of translational medicine. 2010; 8:86. [PubMed: 20849603]

182. Hawes SE, Stern JE, Feng Q, Wiens LW, Rasey JS, Lu H, et al. DNA hypermethylation of tumors from non-small cell lung cancer (NSCLC) patients is associated with gender and histologic type. Lung cancer. 2010; 69:172-9. [PubMed: 19945765]

183. Lockwood WW, Wilson IM, Coe BP, Chari R, Pikor LA, Thu KL, et al. Divergent genomic and epigenomic landscapes of lung cancer subtypes underscore the selection of different oncogenic pathways during tumor development. PloS one. 2012; 7:e37775. [PubMed: 22629454]

184. Christensen BC, Marsit CJ, Houseman EA, Godleski JJ, Longacker JL, Zheng S, et al. Differentiation of lung adenocarcinoma, pleural mesothelioma, and nonmalignant pulmonary tissues using DNA methylation profiles. Cancer research. 2009; 69:6315-21. [PubMed: 19638575]

185. Bishop JA, Benjamin H, Cholakh H, Chajut A, Clark DP, Westra WH. Accurate classification of non-small cell lung carcinoma using a novel microRNA-based approach. Clinical cancer research : an official journal of the American Association for Cancer Research. 2010; 16:610-9. [PubMed: 20068099]

186. Lebanony D, Benjamin H, Gilad S, Ezagouri M, Dov A, Ashkenazi K, et al. Diagnostic assay based on hsa-miR-205 expression distinguishes squamous from nonsquamous non-small-cell lung carcinoma. Journal of clinical oncology : official journal of the American Society of Clinical Oncology. 2009; 27:2030-7. [PubMed: 19273703]

187. Hoffman PC, Mauer AM, Vokes EE. Lung cancer. Lancet. 2000; 355:479-85. [PubMed: 10841143]

188. Field JK, Baldwin D, Brain K, Devaraj A, Eisen T, Duffy SW, et al. CT screening for lung cancer in the UK: position statement by UKLS investigators following the NLST report. Thorax. 2011; 66:736-7. [PubMed: 21724746]

189. Isbell JM, Deppen S, Putnam JB Jr, Nesbitt JC, Lambright ES, Dawes A, et al. Existing general population models inaccurately predict lung cancer risk in patients referred for surgical evaluation. The Annals of thoracic surgery. 2011; 91:227-33. discussion 33. [PubMed: 21172518]

190. Machida EO, Brock MV, Hooker CM, Nakayama J, Ishida A, Amano J, et al. Hypermethylation of ASC/TMS1 is a sputum marker for late-stage lung cancer. Cancer research. 2006; 66:6210-8. [PubMed: 16778195]

191. Leng S, Do K, Yingling CM, Picchi MA, Wolf HJ, Kennedy TC, et al. Defining a gene promoter methylation signature in sputum for lung cancer risk assessment. Clinical cancer research : an official journal of the American Association for Cancer Research. 2012; 18:3387-95. [PubMed: 22510351]

192. de Fraipont F, Moro-Sibilot D, Michelland S, Brambilla E, Brambilla C, Favrot MC. Promoter methylation of genes in bronchial lavages: a marker for early diagnosis of primary and relapsing non-small cell lung cancer? Lung cancer. 2005; 50:199-209. [PubMed: 16043258]

193. Dietrich D, Kneip C, Raji O, Liloglou T, Seegebarth A, Schlegel T, et al. Performance evaluation of the DNA methylation biomarker SHOX2 for the aid in diagnosis of lung cancer based on the analysis of bronchial aspirates. International journal of oncology. 2012; 40:825-32. [PubMed: 22108652] 
194. Schmiemann V, Bocking A, Kazimirek M, Onofre AS, Gabbert HE, Kappes R, et al. Methylation assay for the diagnosis of lung cancer on bronchial aspirates: a cohort study. Clinical cancer research : an official journal of the American Association for Cancer Research. 2005; 11:772834. [PubMed: 16278393]

195. Hu YC, Sidransky D, Ahrendt SA. Molecular detection approaches for smoking associated tumors. Oncogene. 2002; 21:7289-97. [PubMed: 12379873]

196. Simkin M, Abdalla M, El-Mogy M, Haj-Ahmad Y. Differences in the quantity of DNA found in the urine and saliva of smokers versus nonsmokers: implications for the timing of epigenetic events. Epigenomics. 2012; 4:343-52. [PubMed: 22690669]

197. Belinsky SA, Liechty KC, Gentry FD, Wolf HJ, Rogers J, Vu K, et al. Promoter hypermethylation of multiple genes in sputum precedes lung cancer incidence in a high-risk cohort. Cancer research. 2006; 66:3338-44. [PubMed: 16540689]

198. Greenberg AK, Rimal B, Felner K, Zafar S, Hung J, Eylers E, et al. S-adenosylmethionine as a biomarker for the early detection of lung cancer. Chest. 2007; 132:1247-52. [PubMed: 17934114]

199. Shen J, Todd NW, Zhang H, Yu L, Lingxiao X, Mei Y, et al. Plasma microRNAs as potential biomarkers for non-small-cell lung cancer. Laboratory investigation; a journal of technical methods and pathology. 2011; 91:579-87.

200. Ma J, Li N, Guarnera M, Jiang F. Quantification of Plasma miRNAs by Digital PCR for Cancer Diagnosis. Biomarker insights. 2013; 8:127-36. [PubMed: 24277982]

201. Weber DG, Johnen G, Casjens S, Bryk O, Pesch B, Jockel KH, et al. Evaluation of long noncoding RNA MALAT1 as a candidate blood-based biomarker for the diagnosis of non-small cell lung cancer. BMC research notes. 2013; 6:518. [PubMed: 24313945]

202. Shen Y, Wang T, Yang T, Hu Q, Wan C, Chen L, et al. Diagnostic value of circulating microRNAs for lung cancer: a meta-analysis. Genetic testing and molecular biomarkers. 2013; 17:359-66. [PubMed: 23387316]

203. Wang J, Lee JJ, Wang L, Liu DD, Lu C, Fan YH, et al. Value of p16INK4a and RASSF1A promoter hypermethylation in prognosis of patients with resectable non-small cell lung cancer. Clinical cancer research : an official journal of the American Association for Cancer Research. 2004; 10:6119-25. [PubMed: 15447998]

204. Gu J, Berman D, Lu C, Wistuba, Roth JA, Frazier M, et al. Aberrant promoter methylation profile and association with survival in patients with non-small cell lung cancer. Clinical cancer research : an official journal of the American Association for Cancer Research. 2006; 12:7329_ 38. [PubMed: 17189404]

205. Kim JS, Kim JW, Han J, Shim YM, Park J, Kim DH. Cohypermethylation of p16 and FHIT promoters as a prognostic factor of recurrence in surgically resected stage I non-small cell lung cancer. Cancer research. 2006; 66:4049-54. [PubMed: 16618724]

206. Ota N, Kawakami K, Okuda T, Takehara A, Hiranuma C, Oyama K, et al. Prognostic significance of p16(INK4a) hypermethylation in non-small cell lung cancer is evident by quantitative DNA methylation analysis. Anticancer research. 2006; 26:3729-32. [PubMed: 17094392]

207. Suzuki M, Mohamed S, Nakajima T, Kubo R, Tian L, Fujiwara T, et al. Aberrant methylation of CXCL12 in non-small cell lung cancer is associated with an unfavorable prognosis. International journal of oncology. 2008; 33:113-9. [PubMed: 18575756]

208. Seng TJ, Currey N, Cooper WA, Lee CS, Chan C, Horvath L, et al. DLEC1 and MLH1 promoter methylation are associated with poor prognosis in non-small cell lung carcinoma. British journal of cancer. 2008; 99:375-82. [PubMed: 18594535]

209. Usadel H, Brabender J, Danenberg KD, Jeronimo C, Harden S, Engles J, et al. Quantitative adenomatous polyposis coli promoter methylation analysis in tumor tissue, serum, and plasma DNA of patients with lung cancer. Cancer research. 2002; 62:371-5. [PubMed: 11809682]

210. Brock MV, Hooker CM, Ota-Machida E, Han Y, Guo M, Ames S, et al. DNA methylation markers and early recurrence in stage I lung cancer. The New England journal of medicine. 2008; 358:1118-28. [PubMed: 18337602] 
211. Suzuki M, Hao C, Takahashi T, Shigematsu H, Shivapurkar N, Sathyanarayana UG, et al. Aberrant methylation of SPARC in human lung cancers. British journal of cancer. 2005; 92:9428. [PubMed: 15756262]

212. Yoshino M, Suzuki M, Tian L, Moriya Y, Hoshino H, Okamoto T, et al. Promoter hypermethylation of the p16 and Wif-1 genes as an independent prognostic marker in stage IA non-small cell lung cancers. International journal of oncology. 2009; 35:1201-9. [PubMed: 19787276]

213. Xing J, Stewart DJ, Gu J, Lu C, Spitz MR, Wu X. Expression of methylation-related genes is associated with overall survival in patients with non-small cell lung cancer. British journal of cancer. 2008; 98:1716-22. [PubMed: 18414412]

214. Strauss GM, Herndon JE 2nd, Maddaus MA, Johnstone DW, Johnson EA, Harpole DH, et al. Adjuvant paclitaxel plus carboplatin compared with observation in stage IB non-small-cell lung cancer: CALGB 9633 with the Cancer and Leukemia Group B, Radiation Therapy Oncology Group, and North Central Cancer Treatment Group Study Groups. Journal of clinical oncology : official journal of the American Society of Clinical Oncology. 2008; 26:5043-51. [PubMed: 18809614]

215. Kelsey CR, Marks LB, Hollis D, Hubbs JL, Ready NE, D'Amico TA, et al. Local recurrence after surgery for early stage lung cancer: an 11-year experience with 975 patients. Cancer. 2009; 115:5218-27. [PubMed: 19672942]

216. Shoji F, Haro A, Yoshida T, Ito K, Morodomi Y, Yano T, et al. Prognostic significance of intratumoral blood vessel invasion in pathologic stage IA non-small cell lung cancer. The Annals of thoracic surgery. 2010; 89:864-9. [PubMed: 20172144]

217. Barlesi F, Giaccone G, Gallegos-Ruiz MI, Loundou A, Span SW, Lefesvre P, et al. Global histone modifications predict prognosis of resected non small-cell lung cancer. Journal of clinical oncology : official journal of the American Society of Clinical Oncology. 2007; 25:4358-64. [PubMed: 17906200]

218. Seligson DB, Horvath S, McBrian MA, Mah V, Yu H, Tze S, et al. Global levels of histone modifications predict prognosis in different cancers. The American journal of pathology. 2009; 174:1619-28. [PubMed: 19349354]

219. Kikuchi J, Kinoshita I, Shimizu Y, Kikuchi E, Konishi J, Oizumi S, et al. Distinctive expression of the polycomb group proteins Bmil polycomb ring finger oncogene and enhancer of zeste homolog 2 in nonsmall cell lung cancers and their clinical and clinicopathologic significance. Cancer. 2010; 116:3015-24. [PubMed: 20564407]

220. Zhang XY, Dong QG, Huang JS, Huang AM, Shi CL, Jin B, et al. The expression of stem cellrelated indicators as a prognostic factor in human lung adenocarcinoma. Journal of surgical oncology. 2010; 102:856-62. [PubMed: 20818602]

221. Crea F, Sun L, Pikor L, Frumento P, Lam WL, Helgason CD. Mutational analysis of Polycomb genes in solid tumours identifies PHC3 amplification as a possible cancer-driving genetic alteration. British journal of cancer. 2013; 109:1699-702. [PubMed: 23942079]

222. Yang M, Shen H, Qiu C, Ni Y, Wang L, Dong W, et al. High expression of miR-21 and miR-155 predicts recurrence and unfavourable survival in non-small cell lung cancer. European journal of cancer. 2013; 49:604-15. [PubMed: 23099007]

223. Liu Z, Sun M, Lu K, Liu J, Zhang M, Wu W, et al. The long noncoding RNA HOTAIR contributes to cisplatin resistance of human lung adenocarcinoma cells via downregualtion of p21(WAF1/CIP1) expression. PloS one. 2013; 8:e77293. [PubMed: 24155936]

224. Zandberga E, Kozirovskis V, Abols A, Andrejeva D, Purkalne G, Line A. Cell-free microRNAs as diagnostic, prognostic, and predictive biomarkers for lung cancer. Genes, chromosomes \& cancer. 2013; 52:356-69. [PubMed: 23404859]

225. Markou A, Sourvinou I, Vorkas PA, Yousef GM, Lianidou E. Clinical evaluation of microRNA expression profiling in non small cell lung cancer. Lung cancer. 2013; 81:388-96. [PubMed: 23756108]

226. Sanfiorenzo C, Ilie MI, Belaid A, Barlesi F, Mouroux J, Marquette CH, et al. Two panels of plasma microRNAs as non-invasive biomarkers for prediction of recurrence in resectable NSCLC. PloS one. 2013; 8:e54596. [PubMed: 23342174] 
227. Boeri M, Verri C, Conte D, Roz L, Modena P, Facchinetti F, et al. MicroRNA signatures in tissues and plasma predict development and prognosis of computed tomography detected lung cancer. Proceedings of the National Academy of Sciences of the United States of America. 2011; 108:3713-8. [PubMed: 21300873]

228. Hu Z, Chen X, Zhao Y, Tian T, Jin G, Shu Y, et al. Serum microRNA signatures identified in a genome-wide serum microRNA expression profiling predict survival of non-small-cell lung cancer. Journal of clinical oncology : official journal of the American Society of Clinical Oncology. 2010; 28:1721-6. [PubMed: 20194856]

229. Liu XG, Zhu WY, Huang YY, Ma LN, Zhou SQ, Wang YK, et al. High expression of serum miR-21 and tumor miR-200c associated with poor prognosis in patients with lung cancer. Medical oncology. 2012; 29:618-26. [PubMed: 21516486]

230. Silva J, Garcia V, Zaballos A, Provencio M, Lombardia L, Almonacid L, et al. Vesicle-related microRNAs in plasma of nonsmall cell lung cancer patients and correlation with survival. The European respiratory journal. 2011; 37:617-23. [PubMed: 20595154]

231. Wang ZX, Bian HB, Wang JR, Cheng ZX, Wang KM, De W. Prognostic significance of serum miRNA-21 expression in human non-small cell lung cancer. Journal of surgical oncology. 2011; 104:847-51. [PubMed: 21721011]

232. Wei J, Gao W, Zhu CJ, Liu YQ, Mei Z, Cheng T, et al. Identification of plasma microRNA-21 as a biomarker for early detection and chemosensitivity of non-small cell lung cancer. Chinese journal of cancer. 2011; 30:407-14. [PubMed: 21627863]

233. Houseman EA, Accomando WP, Koestler DC, Christensen BC, Marsit CJ, Nelson HH, et al. DNA methylation arrays as surrogate measures of cell mixture distribution. BMC bioinformatics. 2012; 13:86. [PubMed: 22568884]

234. Ramirez JL, Rosell R, Taron M, Sanchez-Ronco M, Alberola V, de Las Penas R, et al. 14-3-3sigma methylation in pretreatment serum circulating DNA of cisplatin-plus-gemcitabinetreated advanced non-small-cell lung cancer patients predicts survival: The Spanish Lung Cancer Group. Journal of clinical oncology : official journal of the American Society of Clinical Oncology. 2005; 23:9105-12. [PubMed: 16361617]

235. Ponomaryova AA, Rykova EY, Cherdyntseva NV, Skvortsova TE, Dobrodeev AY, Zav'yalov AA, et al. RARbeta2 gene methylation level in the circulating DNA from blood of patients with lung cancer. European journal of cancer prevention : the official journal of the European Cancer Prevention Organisation. 2011; 20:453-5.

236. Li B, Ren S, Li X, Wang Y, Garfield D, Zhou S, et al. MiR-21 overexpression is associated with acquired resistance of EGFR-TKI in non-small cell lung cancer. Lung cancer. 2014; 83:146-53. [PubMed: 24331411]

237. Wang YS, Wang YH, Xia HP, Zhou SW, Schmid-Bindert G, Zhou CC. MicroRNA-214 regulates the acquired resistance to gefitinib via the PTEN/AKT pathway in EGFR-mutant cell lines. Asian Pacific journal of cancer prevention : APJCP. 2012; 13:255-60. [PubMed: 22502680]

238. Garofalo M, Romano G, Di Leva G, Nuovo G, Jeon YJ, Ngankeu A, et al. EGFR and MET receptor tyrosine kinase-altered microRNA expression induces tumorigenesis and gefitinib resistance in lung cancers. Nature medicine. 2012; 18:74-82.

239. Zhong M, Ma X, Sun C, Chen L. MicroRNAs reduce tumor growth and contribute to enhance cytotoxicity induced by gefitinib in non-small cell lung cancer. Chemico-biological interactions. 2010; 184:431-8. [PubMed: 20097187]

240. Kitamura K, Seike M, Okano T, Matsuda K, Miyanaga A, Mizutani H, et al. MiR-134/487b/655 Cluster Regulates TGF-beta-Induced Epithelial-Mesenchymal Transition and Drug Resistance to Gefitinib by Targeting MAGI2 in Lung Adenocarcinoma Cells. Molecular cancer therapeutics. 2014; 13:444-53. [PubMed: 24258346]

241. Cao M, Seike M, Soeno C, Mizutani H, Kitamura K, Minegishi Y, et al. MiR-23a regulates TGFbeta-induced epithelial-mesenchymal transition by targeting E-cadherin in lung cancer cells. International journal of oncology. 2012; 41:869-75. [PubMed: 22752005]

242. Cufi S, Bonavia R, Vazquez-Martin A, Oliveras-Ferraros C, Corominas-Faja B, Cuyas E, et al. Silibinin suppresses EMT-driven erlotinib resistance by reversing the high miR-21/low miR-200c signature in vivo. Scientific reports. 2013; 3:2459. [PubMed: 23963283] 
243. Bryant JL, Britson J, Balko JM, Willian M, Timmons R, Frolov A, et al. A microRNA gene expression signature predicts response to erlotinib in epithelial cancer cell lines and targets EMT. British journal of cancer. 2012; 106:148-56. [PubMed: 22045191]

244. Zhan M, Qu Q, Wang G, Zhou H. Let-7c sensitizes acquired cisplatin-resistant A549 cells by targeting ABCC2 and Bcl-XL. Die Pharmazie. 2013; 68:955-61. [PubMed: 24400442]

245. Dong Z, Zhong Z, Yang L, Wang S, Gong Z. MicroRNA-31 inhibits cisplatin-induced apoptosis in non-small cell lung cancer cells by regulating the drug transporter ABCB9. Cancer letters. 2014; 343:249-57. [PubMed: 24099915]

246. Li Y, Li L, Guan Y, Liu X, Meng Q, Guo Q. MiR-92b regulates the cell growth, cisplatin chemosensitivity of A549 non small cell lung cancer cell line and target PTEN. Biochemical and biophysical research communications. 2013; 440:604-10. [PubMed: 24099768]

247. Song L, Li Y, Li W, Wu S, Li Z. MiR-495 enhances the sensitivity of non-small cell lung cancer cells to platinum by modulation of copper-transporting P-type adenosine triphosphatase A (ATP7A). Journal of cellular biochemistry. 2013

248. Qiu T, Zhou L, Wang T, Xu J, Wang J, Chen W, et al. miR-503 regulates the resistance of nonsmall cell lung cancer cells to cisplatin by targeting Bcl-2. International journal of molecular medicine. 2013; 32:593-8. [PubMed: 23856992]

249. Xiang Q, Tang H, Yu J, Yin J, Yang X, Lei X. MicroRNA-98 sensitizes cisplatin-resistant human lung adenocarcinoma cells by up-regulation of HMGA2. Die Pharmazie. 2013; 68:274-81. [PubMed: 23700794]

250. Zhou L, Qiu T, Xu J, Wang T, Wang J, Zhou X, et al. miR-135a/b modulate cisplatin resistance of human lung cancer cell line by targeting MCL1. Pathology oncology research : POR. 2013; 19:677-83. [PubMed: 23640248]

251. Pouliot LM, Shen DW, Suzuki T, Hall MD, Gottesman MM. Contributions of microRNA dysregulation to cisplatin resistance in adenocarcinoma cells. Experimental cell research. 2013; 319:566-74. [PubMed: 23137650]

252. Zang YS, Zhong YF, Fang Z, Li B, An J. MiR-155 inhibits the sensitivity of lung cancer cells to cisplatin via negative regulation of Apaf-1 expression. Cancer gene therapy. 2012; 19:773-8. [PubMed: 22996741]

253. Liu ZL, Wang H, Liu J, Wang ZX. MicroRNA-21 (miR-21) expression promotes growth, metastasis, and chemo- or radioresistance in non-small cell lung cancer cells by targeting PTEN. Molecular and cellular biochemistry. 2013; 372:35-45. [PubMed: 22956424]

254. Zhu W, Xu H, Zhu D, Zhi H, Wang T, Wang J, et al. miR-200bc/429 cluster modulates multidrug resistance of human cancer cell lines by targeting BCL2 and XIAP. Cancer chemotherapy and pharmacology. 2012; 69:723-31. [PubMed: 21993663]

255. Ceppi P, Mudduluru G, Kumarswamy R, Rapa I, Scagliotti GV, Papotti M, et al. Loss of miR-200c expression induces an aggressive, invasive, and chemoresistant phenotype in nonsmall cell lung cancer. Molecular cancer research : MCR. 2010; 8:1207-16. [PubMed: 20696752]

256. Wang Q, Zhong M, Liu W, Li J, Huang J, Zheng L. Alterations of microRNAs in cisplatinresistant human non-small cell lung cancer cells (A549/DDP). Experimental lung research. 2011; 37:427-34. [PubMed: 21787234]

257. Bian HB, Pan X, Yang JS, Wang ZX, De W. Upregulation of microRNA-451 increases cisplatin sensitivity of non-small cell lung cancer cell line (A549). Journal of experimental \& clinical cancer research : CR. 2011; 30:20. [PubMed: 21329503]

258. Zhu W, Zhu D, Lu S, Wang T, Wang J, Jiang B, et al. miR-497 modulates multidrug resistance of human cancer cell lines by targeting BCL2. Medical oncology. 2012; 29:384-91. [PubMed: 21258880]

259. Zhu W, Shan X, Wang T, Shu Y, Liu P. miR-181b modulates multidrug resistance by targeting BCL2 in human cancer cell lines. International journal of cancer Journal international du cancer. 2010; 127:2520-9. [PubMed: 20162574]

260. Wang XC, Wang W, Zhang ZB, Zhao J, Tan XG, Luo JC. Overexpression of miRNA-21 promotes radiation-resistance of non-small cell lung cancer. Radiation oncology. 2013; 8:146. [PubMed: 23777591] 
261. Grosso S, Doyen J, Parks SK, Bertero T, Paye A, Cardinaud B, et al. MiR-210 promotes a hypoxic phenotype and increases radioresistance in human lung cancer cell lines. Cell death \& disease. 2013; 4:e544. [PubMed: 23492775]

262. Salim H, Akbar NS, Zong D, Vaculova AH, Lewensohn R, Moshfegh A, et al. miRNA-214 modulates radiotherapy response of non-small cell lung cancer cells through regulation of p38MAPK, apoptosis and senescence. British journal of cancer. 2012; 107:1361-73. [PubMed: 22929890]

263. Lee KM, Choi EJ, Kim IA. microRNA-7 increases radiosensitivity of human cancer cells with activated EGFR-associated signaling. Radiotherapy and oncology : journal of the European Society for Therapeutic Radiology and Oncology. 2011; 101:171-6. [PubMed: 21676478]

264. Arora H, Qureshi R, Jin S, Park AK, Park WY. miR-9 and let-7g enhance the sensitivity to ionizing radiation by suppression of NFkappaB1. Experimental \& molecular medicine. 2011; 43:298-304. [PubMed: 21464588]

265. Jeong SH, Wu HG, Park WY. LIN28B confers radio-resistance through the posttranscriptional control of KRAS. Experimental \& molecular medicine. 2009; 41:912-8. [PubMed: 19745602]

266. Sharma SV, Lee DY, Li B, Quinlan MP, Takahashi F, Maheswaran S, et al. A chromatinmediated reversible drug-tolerant state in cancer cell subpopulations. Cell. 2010; 141:69-80. [PubMed: 20371346]

267. Gerlinger M, Rowan AJ, Horswell S, Larkin J, Endesfelder D, Gronroos E, et al. Intratumor heterogeneity and branched evolution revealed by multiregion sequencing. The New England journal of medicine. 2012; 366:883-92. [PubMed: 22397650]

268. Kodani M, Igishi T, Matsumoto S, Chikumi H, Shigeoka Y, Nakanishi H, et al. Suppression of phosphatidylinositol 3-kinase/Akt signaling pathway is a determinant of the sensitivity to a novel histone deacetylase inhibitor, FK228, in lung adenocarcinoma cells. Oncology reports. 2005; 13:477-83. [PubMed: 15706421]

269. Yu XD, Wang SY, Chen GA, Hou CM, Zhao M, Hong JA, et al. Apoptosis induced by depsipeptide FK228 coincides with inhibition of survival signaling in lung cancer cells. Cancer journal. 2007; 13:105-13.

270. Choi YH. Induction of apoptosis by trichostatin A, a histone deacetylase inhibitor, is associated with inhibition of cyclooxygenase-2 activity in human non-small cell lung cancer cells. International journal of oncology. 2005; 27:473-9. [PubMed: 16010430]

271. Doi S, Soda H, Oka M, Tsurutani J, Kitazaki T, Nakamura Y, et al. The histone deacetylase inhibitor FR901228 induces caspase-dependent apoptosis via the mitochondrial pathway in small cell lung cancer cells. Molecular cancer therapeutics. 2004; 3:1397-402. [PubMed: 15542778]

272. Tong M, Ding Y, Tai HH. Histone deacetylase inhibitors and transforming growth factor-beta induce 15-hydroxyprostaglandin dehydrogenase expression in human lung adenocarcinoma cells. Biochemical pharmacology. 2006; 72:701-9. [PubMed: 16844092]

273. Kaminskyy VO, Surova OV, Vaculova A, Zhivotovsky B. Combined inhibition of DNA methyltransferase and histone deacetylase restores caspase- 8 expression and sensitizes SCLC cells to TRAIL. Carcinogenesis. 2011; 32:1450-8. [PubMed: 21771726]

274. Nam JS, Ino Y, Kanai Y, Sakamoto M, Hirohashi S. 5-aza-2'-deoxycytidine restores the Ecadherin system in E-cadherin-silenced cancer cells and reduces cancer metastasis. Clinical \& experimental metastasis. 2004; 21:49-56. [PubMed: 15065602]

275. Lockwood WW, Zejnullahu K, Bradner JE, Varmus H. Sensitivity of human lung adenocarcinoma cell lines to targeted inhibition of BET epigenetic signaling proteins. Proceedings of the National Academy of Sciences of the United States of America. 2012; 109:19408-13. [PubMed: 23129625]

276. Rao M, Chinnasamy N, Hong JA, Zhang Y, Zhang M, Xi S, et al. Inhibition of histone lysine methylation enhances cancer-testis antigen expression in lung cancer cells: implications for adoptive immunotherapy of cancer. Cancer research. 2011; 71:4192-204. [PubMed: 21546573]

277. Lawless MW, O'Byrne KJ, Gray SG. Oxidative stress induced lung cancer and COPD: opportunities for epigenetic therapy. Journal of cellular and molecular medicine. 2009; 13:2800 21. [PubMed: 19602054] 
278. Rangwala S, Zhang C, Duvic M. HDAC inhibitors for the treatment of cutaneous T-cell lymphomas. Future medicinal chemistry. 2012; 4:471-86. [PubMed: 22416775]

279. Juergens RA, Wrangle J, Vendetti FP, Murphy SC, Zhao M, Coleman B, et al. Combination epigenetic therapy has efficacy in patients with refractory advanced non-small cell lung cancer. Cancer discovery. 2011; 1:598-607. [PubMed: 22586682] 
Table 1

Select genes frequently reported to undergo promoter methylation in lung cancer.

\begin{tabular}{|c|c|c|c|c|}
\hline Gene & Locus (Ensembl) & Frequency in NSCLC & Gene function(s) & References \\
\hline$C D K N 2 A / p 16 I N K 4 a$ & 9.21 .3 & $22-47 \%{ }^{a}$ & $\begin{array}{l}\text { Cyclin Dependent Kinase Inhibitor } 2 \mathrm{~A} / \mathrm{p} 16 \text { : } \\
\text { key TSG involved in cell cycle arrest at the } \\
\text { G1/S-phase checkpoint through inhibition of } \\
\text { CDK4/6 }\end{array}$ & {$[5,16-31]$} \\
\hline FHIT & $3 \mathrm{p} 14.2$ & $34-47 \% a$ & $\begin{array}{l}\text { Fragile Histidine Triad: member of the } \\
\text { histidine triad family involved in purine } \\
\text { metabolism; TSG that regulates genes essential } \\
\text { for cell proliferation and induction of apoptosis }\end{array}$ & {$[16,23,27,34-37]$} \\
\hline$A P C$ & $5 q 22.2$ & $30-96 \% a$ & $\begin{array}{l}\text { Adenomatous Polyposis Coli: TSG that acts as } \\
\text { a negative regulator of Wnt and also is } \\
\text { involved in cell migration and adhesion, } \\
\text { transcriptional activation, and apoptosis }\end{array}$ & $\begin{array}{l}{[16,17,27,28,38-} \\
41]\end{array}$ \\
\hline RASSF1A & $3 \mathrm{p} 21.31$ & $25-45 \% a$ & $\begin{array}{l}\text { Ras Association (RalGDS/AF-6) Domain } \\
\text { Family Member 1: putative TSG involved in } \\
\text { apoptosis and cell cycle control }\end{array}$ & $\begin{array}{l}{[5,16,17,27,28,31,} \\
36-38,42-45]\end{array}$ \\
\hline$D A P K$ & $9 q 21.33$ & $16-45 \%{ }^{a}$ & $\begin{array}{l}\text { Death-associated protein kinase: putative TSG } \\
\text { involved in apoptotic signaling }\end{array}$ & {$[16,28,29,44,46]$} \\
\hline$R A R \beta$ & $9 \mathrm{p} 24.2$ & $26-45 \% b$ & $\begin{array}{l}\text { Retinoic acid receptor beta: involved in cell } \\
\text { growth and differentiation }\end{array}$ & {$[16,17,37,40,47]$} \\
\hline$M G M T$ & $10 \mathrm{q} 26.3$ & $11-38 \% a$ & $\begin{array}{l}\text { O-6-methylguanine DNA methyltransferase: } \\
\text { DNA repair enzyme that removes alkyl lesions } \\
\text { from the O6 position of guanine }\end{array}$ & {$[17,22,48-50]$} \\
\hline SHOX2 & $3 q 25.32$ & $91-95 \% c$ & $\begin{array}{l}\text { Homeobox family gene involved in gene } \\
\text { transcription with putative involvement in cell } \\
\text { growth and differentiation }\end{array}$ & {$[51,52]$} \\
\hline$R U N X 3$ & $1 \mathrm{p} 36.11$ & $25 \% d$ & $\begin{array}{l}\text { Runt-domain containing transcription factor } \\
\text { that functions as a TSG }\end{array}$ & {$[36,53-57]$} \\
\hline $\mathrm{CDH} 13$ & $16 \mathrm{q} 23.3$ & $28-30 \% b$ & $\begin{array}{l}\text { H-cadherin: TSG involved in regulation of cell } \\
\text { growth, proliferation, and apoptosis }\end{array}$ & {$[5,28,31,40,58]$} \\
\hline $\mathrm{CDH} 1$ & $16 \mathrm{q} 22.1$ & $12-58 \% a$ & $\begin{array}{l}\text { E-cadherin; TSG that negatively regulates cell- } \\
\text { cell adhesion, growth, motility, and } \\
\text { proliferation; loss of function in cancer is } \\
\text { thought to increase proliferation, invasion, and } \\
\text { metastasis }\end{array}$ & {$[17,28,38,42,58]$} \\
\hline$T S L C 1$ & $11 \mathrm{q} 23.3$ & $37-44 \% d$ & $\begin{array}{l}\text { Cell adhesion molecule 1: TSG involved in } \\
\text { cell-cell adhesion }\end{array}$ & [59-61] \\
\hline ASC/TMS1 & $16 \mathrm{p} 11.2$ & $35-47 \%^{a}$ & $\begin{array}{l}\text { PYD And CARD Domain-Containing Protein: } \\
\text { crucial mediator of apoptosis and inflammation }\end{array}$ & {$[62,63]$} \\
\hline$D A L 1$ & $18 \mathrm{p} 11.31$ & $55-57 \% d$ & $\begin{array}{l}\text { Erythrocyte Membrane Protein Bank 4.1-Like } \\
3 \text {; TSG involved in cell cycle arrest and } \\
\text { apoptosis }\end{array}$ & {$[59,64]$} \\
\hline PTEN & $10 \mathrm{q} 23.31$ & $26 \% b$ & $\begin{array}{l}\text { Phosphatase And Tensin Homolog: TSG } \\
\text { involved in cell cycle control and survival by } \\
\text { acting as a negative regulator of the AKT/PKB } \\
\text { pathway }\end{array}$ & {$[22,65,66]$} \\
\hline GSTP1 & $11 q 13.2$ & $15 \% b$ & $\begin{array}{l}\text { Glutathione S-Transferase P1: functions as a } \\
\text { phase II xenobiotic detoxification enzyme }\end{array}$ & {$[17,27,67,68]$} \\
\hline
\end{tabular}

Abbreviations: NSCLC $=$ non-small cell lung cancer; SCLC $=$ small cell lung cancer; TSG $=$ tumor suppressor gene

${ }^{a}$ Estimate based on [32, 33]

${ }^{b}$ Estimate based on [32]

${ }^{c}$ Estimate includes NSCLC and SCLC [51, 52] 
$d_{\text {Estimate based on [33] }}$ 


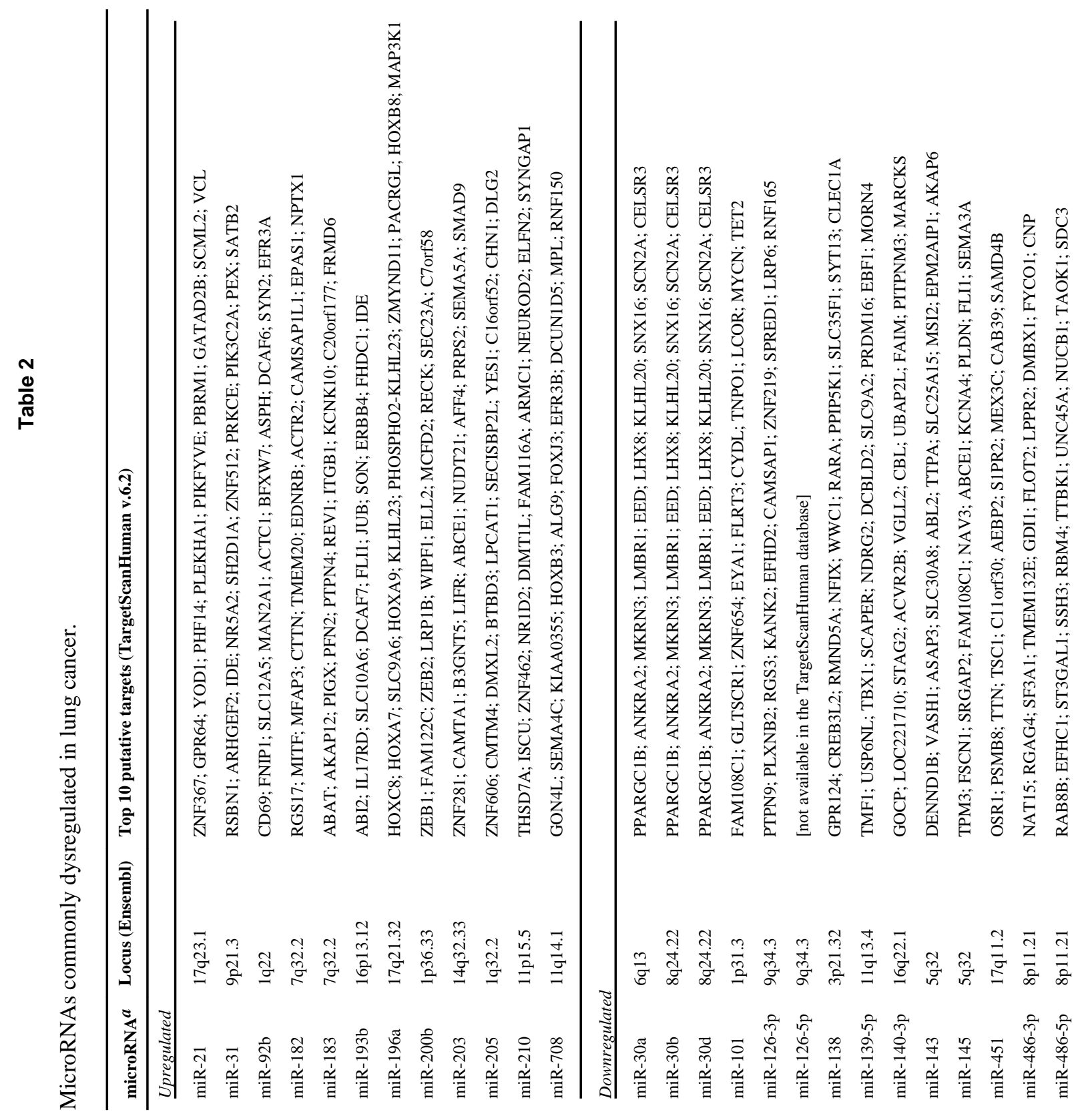




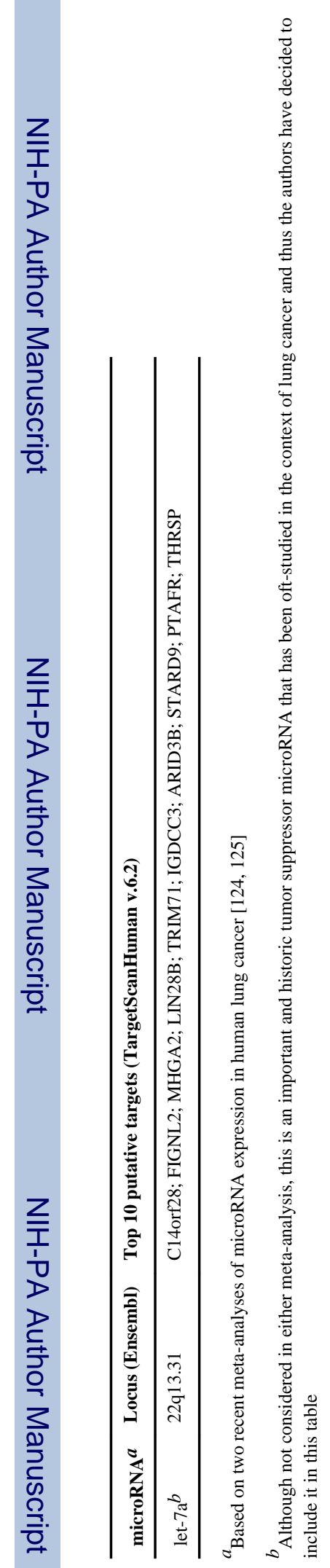




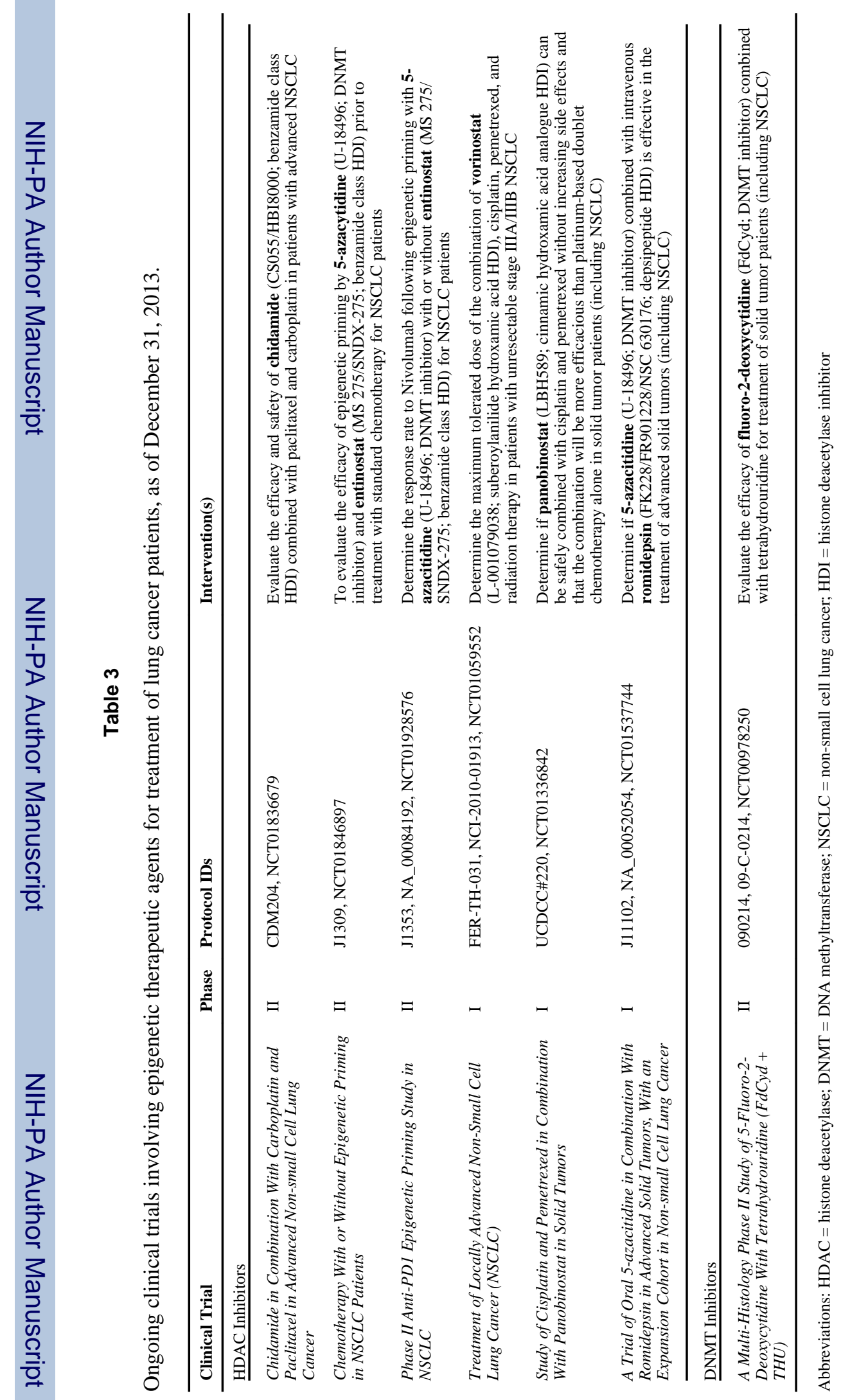

